\title{
5. AZ ISKOLA LÉGKÖRE
}

\author{
GASKÓ KRISZTINA - SZÜCS IDA
}

\section{Az iskolai légkör fogalmának értelmezése a kutatásban}

Az iskolai légkör elemzéséhez ma jellemzően többdimenziós megközelítést (Arter, 1987; Cohen et al., 2009; Santiago, 2002; Thapa et al., 2013; idézi Széll, 2016) használunk, amelynek értelmében az alábbi dimenziókat vizsgálhatjuk:

- az iskola fizikai és érzelmi biztonsága;

- az iskolán belüli interperszonális kapcsolatrendszer;

- az iskolán kívüli szereplőkkel, más iskolákkal kialakított partnerkapcsolatok;

- a tanítás és tanulás pedagógiai környezete, pedagógiai gyakorlatok és lehetőségek minősége;

- a cél-, norma- és értékrendszer;

- a pedagógiai munka különböző értékelési szempontjai;

- az együttműködések formái, jellemzői, szakmai ismeretek és tartalmak egymással történő megosztásának módozatai;

- az iskolafejlesztés komplex folyamata;

- az iskolák strukturális és tárgyi környezete.

A „szakmai fejlesztő/fejlődő iskola” koncepciója (Kotschy, 2003) alapján az iskola légkörét meghatározó tényezőket a következőkben azonosíthatjuk:

- Közös értékek és ezek iránti meggyőződés; ezek közül a legfontosabb a fejlődéshez való viszonyulás.

- Demokratikus intézményvezetés, melyben az iskola polgárai bevonódnak a döntéshozatalba, a pedagógusok, oktatók nemcsak egyenrangú félként, hanem szakemberként is részt vesznek ezekben a döntésekben.

- Az egyéni fejlödés személyre szabott támogatása, a tanulók aktív részvételének elősegítése a tanulási-tanítási folyamatokban.

- A pedagógusok folyamatos önfejlesztésére való törekvése és ennek támogatása.

- Az optimális munkafolyamatok és munkakörülmények megteremtésének elősegítése (idő és környezet a közös munkához és fejlődéshez).

- A kutatás, fejlesztés iránti elkötelezödés a szervezet minden szintjén. 
A „szakmai fejlesztő/fejlődő iskola” koncepciója (Kotschy, 2003) szempontjából jó lehetőségnek tűnik a kreativitást, a kreatív tanulást támogató iskolai légkör értelmezése (Ekvall, 1983 alapján). Ebben a megközelítésben mind a tanulók, mind a pedagógusok, mind a szervezet tanulása, fejlődése, önfejlesztése értelmezhető.

Ekvall (1983) a szervezeti klímát úgy értelmezi, mint a szervezet mindennapi életében megfigyelhetö, gyakori, hétköznapi jelenségeket, viselkedésmintákat, érzéseket, attitüdöket. Ezek a tényezők jelentős befolyást gyakorolnak a szervezet formális és informális müködésére, a szervezet tagjainak elégedettségére, a munkavégzés színvonalára és a kreativitásra. Úgy véli, hogy a klíma nem csupán a szervezet tagjainak a szubjektív észleleteit jelenti, hanem a szervezet objektív, meghatározott, azaz megragadható, leírható jellemzője. A klíma, a kultúra fogalmával szembeállítva, egy annál sokkal kézzelfoghatóbb jelenség, melyet a fizikai környezet, a társas kapcsolatok és az elvárások határoznak meg.

A kreatív klíma meghatározó jelentőségére elsőként Ekvall (1983) hívta fel a figyelmet, aki szerint a kreativitást serkentő szociális környezeti tényezők közé tartozik a célok kitüzése és az azok felé történö elkötelezödés, a megfelelö mértékü autonómia és szabadság a feladatmegoldásban, az elegendö idó, a visszajelzések, az elismerés minden fajtája, a bátoritó légkör, az új ötleteket, elgondolásokat támogató hozzáállás. A jól kiválasztott és meghatározott feladatok, a kockázatvállaló magatartás és a hibázás lehetöségének elfogadása szintén segíti a kreatív produktumok létrejöttét (Mathisen és Einarsen, 2004). Ezek a tényezők az iskolai tanulási klíma meghatározásában is kiemelkedő jelentőségüek.

Ekvall koncepciójára építve dolgozta ki Péter-Szarka Szilvia és munkacsoportja a Kreatív Iskolai Klíma kérdőívet, amely az az alábbi tényezőket méri a diákok körében:

- Csoport: csoportlégkör, csoportbizalom.

- Nyitottság: a tapasztalatokra, az újdonságokra való nyitottság.

- Bátorítás a sokféleségre, autonómiára: kockázatvállalás és a sokféleség tolerálása (ha a csoport alapvetően toleráns, és elfogadja a sokféleséget, az lehetőséget teremt az egyéni kockázatvállalásra, az önálló gondolatok és az autonómia felvállalására).

- Kihívás, érdekesség: kitartás, önfegyelem, motiváció, a feladatok értelmessége, a célok iránti elkötelezettség.

- Korlátok: korlátokkal és presszióérzéssel kapcsolatos viszonyulások (elsősorban az iskola merevségéből és az időhiányból fakadó kellemetlen körülmények).

Az egri gyakorlóiskola légkörének megismerése érdekében a felső tagozatos és középiskolás diákokkal töltettük ki a kérdőív rövidített, minden területen négy-négy állítást tartalmazó változatát.

Az iskolai klíma pedagógusok által történő értékelésére számos, a nevelőtestületi légkört feltáró mérőeszköz áll rendelkezésre, kutatásunk során azonban olyan koncepciót és kérdőívet szerettünk volna alkalmazni, amely többdimenziós megközelítést használ. 
A választásunk a Timár Éva (1999, 2006) által kidolgozott Pedagógiai Klíma Percepció tesztre esett, mely a következő tényezőket méri:

- Az arculat alskálában a pozitív pólust olyan klíma képviseli, amelyben a pedagógusok elismerésszükséglete az iskola pozitív külső képe által elégül ki. Az ellentétes végponthoz közel álló iskolát az jellemzi, hogy az iskoláztatásban érintettek nincsenek jó véleménnyel sem a tanulókkal szemben támasztott követelményekről, sem az iskola pedagógusairól.

- A beleszólás alskálában szemben áll egymással az olyan klíma, ahol van a pedagógusok szavának súlya, ahol az autonómiaszükséglet kielégitésére, az önmegvalósitásra adottak a feltételek, sok területen meghallgatják a tantestületi tagok kéréseit, véleményét, illetve az olyan, amelyben szó sem lehet a tanári beleszólásról, ahol a pedagógusok elől elzárják az aktivitás, önmegvalósítás, önkifejezés lehetőségét.

- A kollégákhoz való viszony alskála ütközteti a szociális szükségletek sokoldalú kielégítésére alkalmat adó klímát a kapcsolatszükségletet teljesen figyelmen kívül hagyóval. A skála pozitív végén az emberi viszonyokban az egymás iránti őszinte érdeklődés, empátia, bizalom, jóindulat, baráti érzelem dominál. Az affiliációs törekvések jellemzőek. A másik véglet esetén olyan a klíma, hogy semmilyen téren nem fedezhető fel az egységesség, a többiekkel való azonosulási törekvés.

- A kommunikáció elnevezésủ alskálában az olyan tantestületi klíma, ahol a pedagógusok kommunikációs kapcsolatai nagymértékben hozzájárulnak a személyiség identifikációs, affiliációs és empátiatörekvéseinek a kiteljesítéséhez, ütközik azzal, amelyben torzult és beszűkült kommunikációs háló működik.

- A munkához való viszony alskálának a segítségével az olyan klíma, amelyben a tantestületi tagokra magas szintű hivatástudat, a pálya iránti nagyfokú elkötelezettség, szakmaszeretet jellemző - azaz az önérvényesítés, önkifejezés belülről jövő igénye kielégülhet - szemben áll azzal, ahol lényegében elhibázottnak érzik a kollégák a pályaválasztásukat.

- A vezetési stílus alskála ütközteti azt a klímát, amelyben a tantestületi tagok kapcsolat-, aktivitás- és értékelésszükségleteiknek kielégítésére módot ad az igazgató, az olyannal, amelyben a vezetési felfogás meggátolja a pedagógusokat abban, hogy e területeken fellépő igényeiknek érvényt szerezzenek.

Az egri gyakorlóiskola vizsgálata során a kérdőív rövidített, 26 állítást tartalmazó változatát használtuk. 


\section{Kutatási kérdések}

1. Mennyire gondolkodnak egységesen az iskolában dolgozó pedagógusok az iskola legfontosabb értékeiről, céljairól? Mit érzékelnek ezekből az értékekből a tanulók?

2. Milyennek ítélik meg a tanulók, a tanárok az iskola működését meghatározó együttmúködéseket? Mi jellemzi az iskola szervezeti kultúráját?

3. Milyen identitása van az iskola polgárainak: mit jelent „gyakorlósnak” lenni?

4. Mi jellemzi az iskola vezetési kultúráját a különböző szinteken, szerepekben? Hogyan viszonyulnak az iskola polgárai a vezetéshez, irányításhoz?

\section{A mérőeszközökben alkalmazott kérdések}

Az alábbiakban azokat a kérdéseket tekintjük át, amelyeket célozottan az iskolai légkör megismeréséhez szerettünk volna felhasználni. Ezeken túlmenően természetesen a kérdőívek más kérdései is lehetőséget biztosítottak az iskolai légkör bizonyos aspektusainak mérésére.

\subsection{A felső tagozatos és középiskolás tanulói kérdőív vonatkozó kérdései}

- Az Iskolai Kreatív Klíma kérdőív rövidített, 20 itemes változatát használtuk fel a felső tagozatos és középiskolás diákok kérdőíveiben. A válaszadást lehetővé tevő számskálát ötfokúra alakítottuk át a kérdőívek más kérdéseihez hasonló értelmezés biztosítása érdekében. A kérdőívben a diákoknak az egyes állításokról azt kell eldönteniük, hogy az véleményük szerint mennyire jellemző általában az iskolai tanóráikra.

- Az iskolára jellemző 12 tulajdonságból álló lista esetében arra kértük a diákokat, hogy egy ötfokú skála segítségével határozzák meg, az adott tulajdonság mennyire jellemző az iskolára.

\subsection{A tanári kérdőív vonatkozó kérdései}

- A Pedagógiai Klíma Percepció teszt rövidített változatát használtuk, melyben arra kértük a pedagógusokat, hogy ítéljék meg 26 állítás esetében, hogy azok mennyire jellemzőek rájuk. A megítélést ötfokú skála segítségével biztosítottuk, melynek elnevezéseit a kérdőív többi kérdésének elnevezéséhez igazítottuk.

- Ezt a kérdőívet egészítettük ki további nyolc, általunk fontosnak tartott állítással, amelyre ugyanolyan módon kértük a válaszok megadását.

- Megfogalmaztunk hét alapvető értéket, amelyek rangsorolását kértük a pedagógusoktól egytől hétig. 
- Az iskolára jellemző 12 tulajdonságból álló lista esetében arra kértük a pedagógusokat, hogy egy ötfokú skála segítségével határozzák meg, az adott tulajdonság mennyire jellemző az iskolára.

\subsection{A szülői kérdőív vonatkozó kérdései}

- Az iskolára jellemző 12 tulajdonságból álló lista esetében arra kértük a szülőket, hogy egy ötfokú skála segítségével határozzák meg, az adott tulajdonság mennyire jellemző az iskolára.

\section{Eredmények}

\subsection{Az iskolai légkör jellemzői a pedagógusok válaszai alapján}

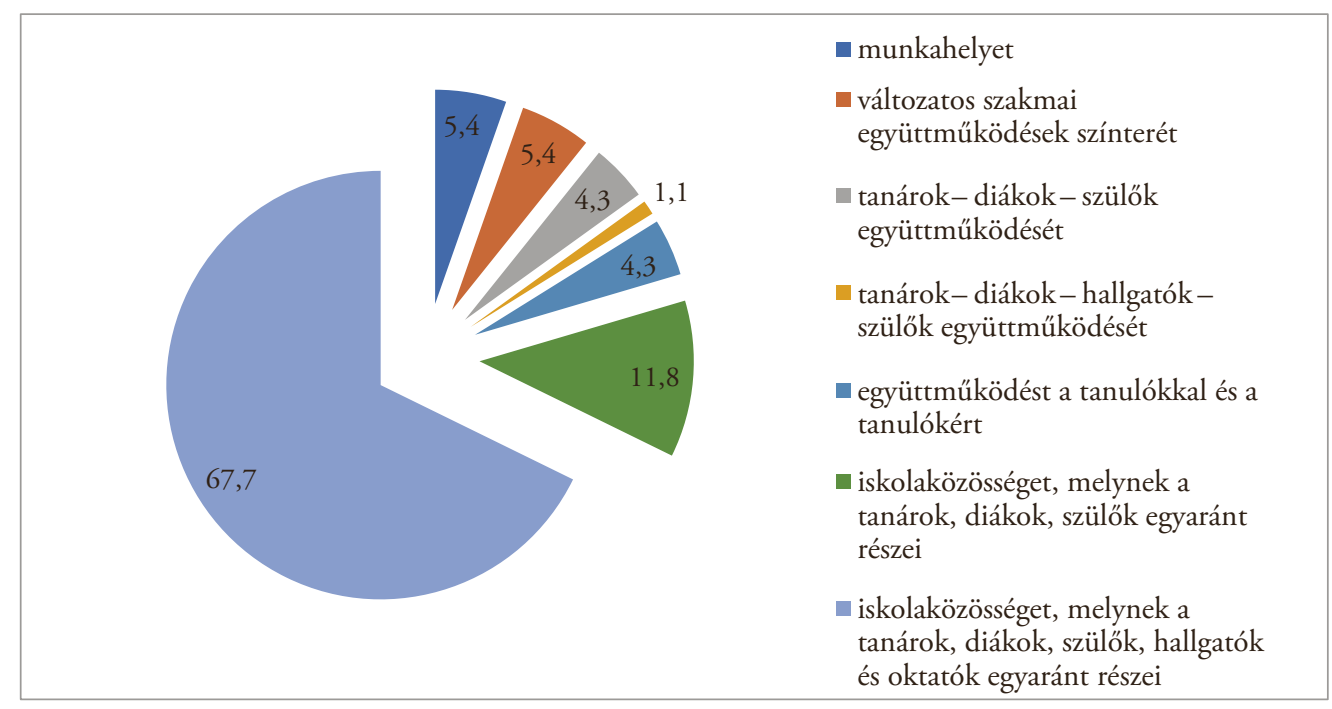

5.1. ábra: A „Mit jelent az Ön számára a gyakorlóiskola?” kérdésre adott válaszok relatív gyakorisági megoszlása a pedagógusok körében $(\mathrm{N}=95)$

Az eredmények szerint az egri gyakorlóiskolában dolgozó pedagógusok túlnyomó többsége (67,7\%) úgy tekint az iskolára, mint iskolaközösségre, amelynek a tanárok, diákok, szülők, hallgatók és oktatók egyaránt részei, s e tekintetben nem mutatkozik szignifikáns különbség a két iskolaépületben dolgozó pedagógusok válaszaiban $(\mathrm{p}=0,359)$ (1.ábra). 


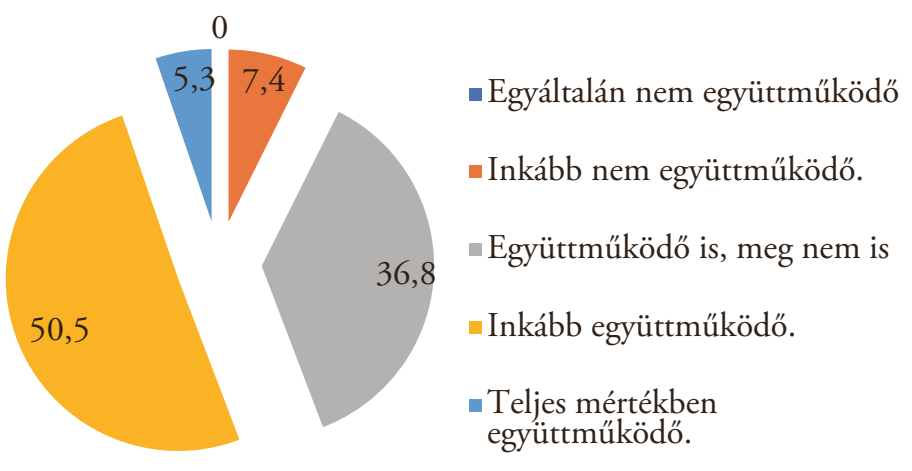

5.2. ábra: A „Milyennek értékeli a két épület nevelőtestülete közötti együttmüködést?" kérdésre adott válaszok relatív gyakorisági megoszlása a pedagógusok körében $(\mathrm{N}=95)$

A két épület nevelőtestülete közötti együttműködést a pedagógusok többsége inkább együttműködőnek (50,5\%) vagy teljes mértékben együttműködőnek (5,3\%) tartják, de a tanárok számottevő része (36,8\%) vegyesen ítéli meg a kérdést („együttműködő is, meg nem is"). A két épületben dolgozó pedagógusok válaszaiban ezúttal sem mutatkozik szignifikáns különbség $(\mathrm{p}=0,068)(2$.ábra $)$.

\begin{tabular}{|c|c|}
\hline Az iskola értékei & $\begin{array}{c}\text { Rangpontszámok } \\
\text { átlaga }\end{array}$ \\
\hline A közös teljesítmények kiemelése, elismerése. & 2,86 \\
\hline A hibák, gyengeségek helyett a fejlődési lehetőségek keresése. & 2,88 \\
\hline Ösztönzés és lelkesítés a kényszer helyett. & 2,91 \\
\hline A tanulók egyéni igényeire és szükségleteire való odafigyelés. & 2,94 \\
\hline Az egymástól tanulás lehetőségeinek keresése, preferálása. & 3,28 \\
\hline Az egyéni fejlödési ütem figyelembevétele. & 3,37 \\
\hline Demokratikus múködés a tekintélyelvűség helyett. & 3,37 \\
\hline
\end{tabular}

5.1. táblázat: $\mathrm{Az}$ „Ön szerint mennyire jellemzőek az iskolára az alábbi értékek?”' kérdésre adott pedagógusi válaszok rangpontszámainak átlaga $(\mathrm{N}=125)$

1 A kérdéshez tartozó instrukció: „Kérjük, rangsorolja az egyes értékeket oly módon, hogy 1-essel jelöli azt, amelyiket a legjellemzőbbnek gondolja, és 7-essel azt, amelyiket a legkevésbé! Kérjük, egy számot csak egy érték jellemzésére használjon!" 
A pedagógusokat arra kértük, hogy az általunk megadott hét értéket rangsorolják az alapján, hogy szerintük azok mennyire jellemzőek az iskolára (1. táblázat). Az eredmények azt jelzik, hogy a pedagógusok szerint „A közös teljesítmények kiemelése, elismerése” (rangpontszám átlag = 2,86), a „A hibák, gyengeségek helyett a fejlődési lehetőségek keresése” (rangpontszám átlag = 2,88) és az „Ösztönzés és lelkesítés a kényszer helyett” (rangpontszám átlag = 2,91) a leginkább jellemző az iskolára. Ugyanakkor „Az egymástól tanulás lehetőségeinek keresése, preferálása” (rangpontszám átlag = 3,28), „Az egyéni fejlődési ütem figyelembevétele” (rangpontszám átlag = 3,37) és a „Demokratikus müködés a tekintélyelvüség helyett” (rangpontszám átlag = 3,37) a legkevésbé jellemző értékek az adatok alapján. Az eredmények tehát azt mutatják, hogy bár a közös teljesítmények elismerése a legjellemzőbb érték a pedagógusok szerint, mégis az értékek közötti választásban mutatkozó kis eltérések miatt nincs igazán kiemelkedő érték a pedagógusok megítélése szerint.

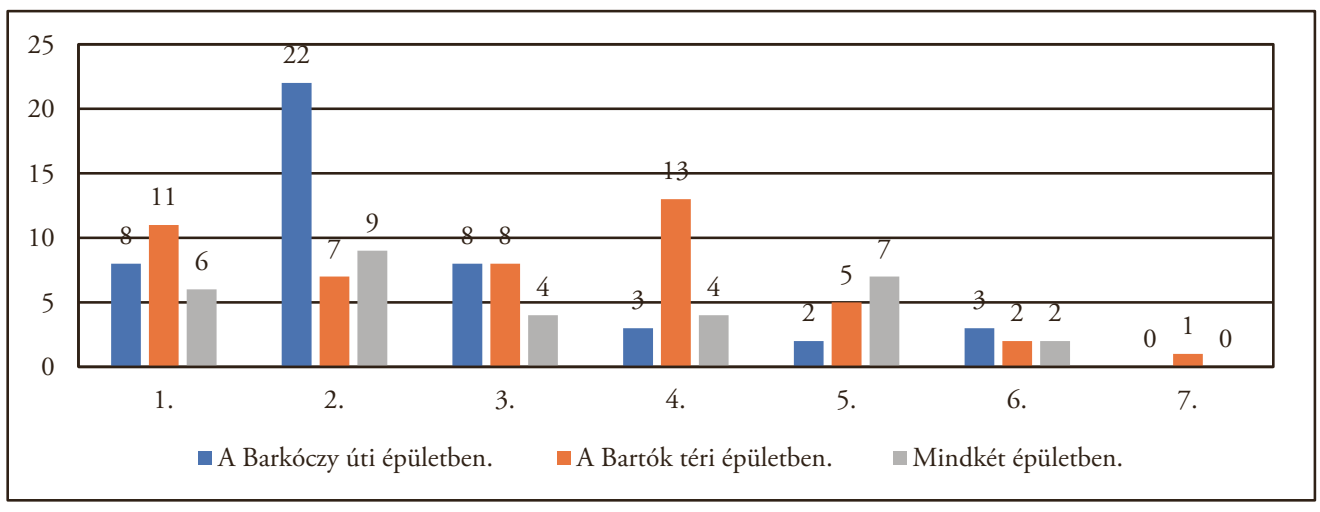

5. 3. ábra: „A hibák, gyengeségek helyett a fejlődési lehetőségek keresése” állítás rangsorolásaként adott válaszok abszolút gyakorisági megoszlása a két épületben tanító pedagógusok csoportjaiban $(\mathrm{p}=0,027 ; \mathrm{N}=125)$

„A hibák, gyengeségek helyett a fejlődési lehetőségek keresése” érték megítélésében szignifikáns különbséget tapasztaltunk a különböző épületekben dolgozó pedagógusok részmintái között $(\mathrm{p}=0,027)$. Ahogy a 3. ábra is jól mutatja, ezt az állítást pozitívabban értékelték a Barkóczy úti épületben dolgozó pedagógusok, hiszen a Barkóczy úti épületben dolgozók 82,6 százaléka (38fó) rangsorolta azt az 1-3. helyre, míg a Bartók téri épületben dolgozóknak csupán 55,3 százaléka (26 fö) tette ugyanezt. A többi érték rangsorolásában nem mutatkoznak szignifikáns eltérések a pedagógusok csoportjai között. 


\begin{tabular}{|l|c|c|c|c|}
\hline & Átlag & Szórás & Minimum & Maximum \\
\hline nyitott a külvilágra & 4,23 & 0,750 & 2 & 5 \\
\hline fejlődésre ösztönző & 4,19 & 0,719 & 2 & 5 \\
\hline támogató & 4,07 & 0,789 & 1 & 5 \\
\hline jól irányított & 4,02 & 0,825 & 2 & 5 \\
\hline közösségi & 3,87 & 0,789 & 2 & 5 \\
\hline izgalmas, érdekes & 3,83 & 0,834 & 1 & 5 \\
\hline demokratikus & 3,35 & 0,931 & 1 & 5 \\
\hline folyton változó & 3,34 & 1,154 & 1 & 5 \\
\hline szórakoztató, bulis & 2,61 & 1,003 & 1 & 5 \\
\hline korlátozó & 2,45 & 0,976 & 1 & 5 \\
\hline régimódi & 1,88 & 0,849 & 1 & 4 \\
\hline rideg & 1,60 & 0,721 & 1 & 4 \\
\hline
\end{tabular}

5.2. táblázat: Az „Ön szerint mennyire jellemzőek az alábbi tulajdonságok az iskolára?” kérdésre adott válaszok átlaga, szórása, minimuma és maximuma $(\mathrm{N}=95)$

$\mathrm{Az}$ „Ön szerint mennyire jellemzőek az alábbi tulajdonságok az iskolára?” kérdésre adott válaszok azt jelzik (2. táblázat), hogy a pedagógusok szerint elsősorban a külvilágra való nyitottság (átlag $=4,23$; szórás $=0,750$ ) és a fejlődésre való ösztönzés (átlag $=4,19$; szórás $=0,719)$ a legjellemzőbb tulajdonsága a gyakorlóiskolának.

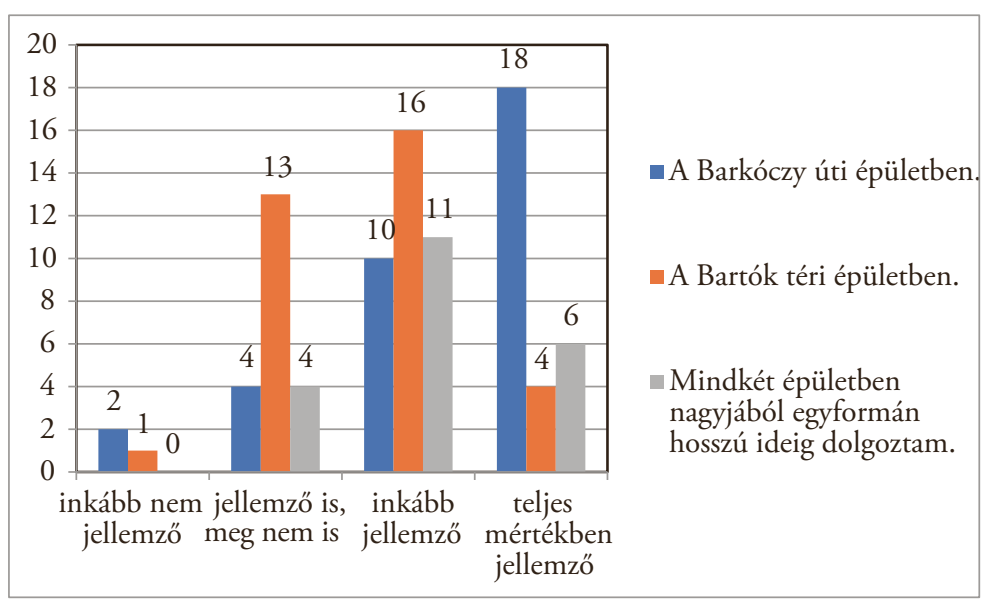

5. 4. ábra: Az iskola „jól irányítottságának” megítélésére adott válaszok abszolút gyakorisági megoszlása a két épületben tanító pedagógusok csoportjaiban

$$
(\mathrm{p}=0,030 ; \mathrm{N}=89)
$$


Ugyanakkor az eredmények az egyik jellemző esetében szignifikáns különbséget ( $\mathrm{p}$ = 0,030) jeleznek a két épületben dolgozó pedagógusok megítélésében (4.ábra). Ezek szerint azt, hogy az iskolára mennyire igaz az, hogy „jól irányított” a két épületben tanító pedagógusok csoportjai eltérően értékelik: a Barkóczy úti épületben dolgozók 82,4 százaléka (28 fó) egyértelműen jellemzőnek tartja a jól irányítottságot az iskolára, míg a Bartók téri épület tanárainak csak 60,6 százaléka (20fö) vélekedik hasonlóképp, és azoknak, akik mindkét épületben nagyjából egyformán hosszú ideig dolgoztak, 81 százaléka (17fó) állította ugyanezt. Az eredmények alapján azt mondhatjuk, hogy a csak a Bartók téri épületben dolgozó pedagógusok elégedetlenebbek az iskola irányításával, mint a többi tanár.

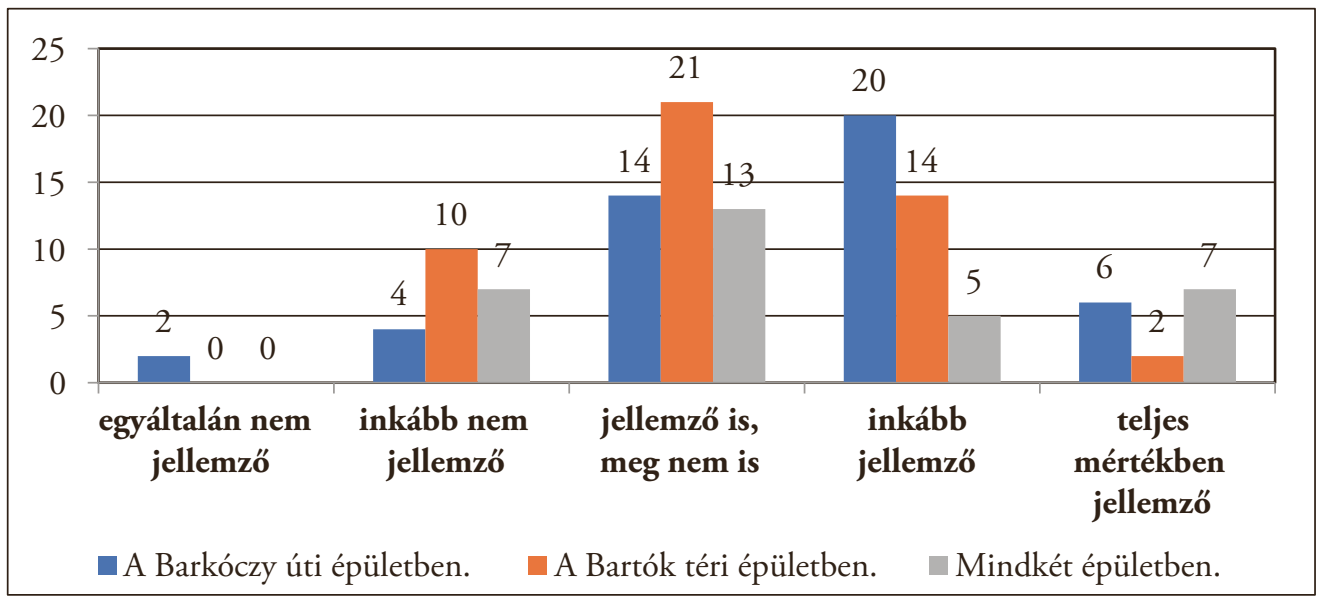

5. 5. ábra: Az iskola „demokratikusságának” megítélésére adott válaszok abszolút gyakorisági megoszlása a két épületben tanító pedagógusok csoportjaiban

$$
(\mathrm{p}=0,027 ; \mathrm{N}=125)
$$

Ugyanígy eltéréseket tapasztaltunk a pedagógusok között az iskola „demokratikusságának" megítélésében (5. ábra): a Barkóczy úti épületben tanító pedagógusok több mint fele (56,5\%, 26 fó) vélekedik úgy, hogy az intézményre inkább vagy teljes mértékben jellemző a demokratikusság, míg a Bartók téri épületben tanító pedagógusoknak 34,1 százaléka (16 fö) gondolja ugyanezt, a mindkét épületben dolgozó tanároknak pedig 37,5 százaléka (12 fö; $\mathrm{p}=0,027$ ).

Mindez arra enged következtetni, hogy a Barkóczy úti épületben dolgozó pedagógusok nemcsak az intézmény irányításáról, de annak demokratikus múködésmódjáról is pozitívabb véleménnyel rendelkeznek.

A következőkben a pedagógiai klíma érzékelésére vonatkozó pedagógusnézeteket mutatjuk be a Pedagógiai Klíma Percepció teszt (Tímár Éva, 1999, 2006) kapott értékei alapján. 


\begin{tabular}{|c|c|c|c|c|c|}
\hline $\begin{array}{l}\text { Alskála } \\
\text { betüjele }\end{array}$ & Állítások & Min. & Max. & Átlag & Szórás \\
\hline (Ko) & $\begin{array}{l}\text { Szívesen veszek részt a munkahelyi } \\
\text { összejöveteleken. }\end{array}$ & 1 & 5 & 4,06 & 0,961 \\
\hline (Ko) & $\begin{array}{l}\text { Megbeszélem a kollégákkal a tanítással } \\
\text { kapcsolatos problémáimat. }\end{array}$ & 2 & 5 & 4,07 & 0,891 \\
\hline (Ko) & A tanáriban jókat szoktunk beszélgetni. & 1 & 5 & 2,14 & 0,910 \\
\hline (Ko) & $\begin{array}{l}\text { Minden kollégával tudok együtt } \\
\text { dolgozni. }\end{array}$ & 1 & 5 & 3,97 & 0,772 \\
\hline$(\mathrm{Kv})$ & $\begin{array}{l}\text { A tantestületünkben vannak kiközösített } \\
\text { kollégák. }\end{array}$ & 1 & 5 & 1,76 & 0,893 \\
\hline$(\mathrm{Kv})$ & Hiányzik a bizalom a kollégák között. & 1 & 5 & 3,41 & 1,071 \\
\hline$(\mathrm{Kv})$ & Néhány kollégát alig ismerek. & 1 & 5 & 3,98 & 0,788 \\
\hline$(\mathrm{Kv})$ & $\begin{array}{l}\text { A mi intézményünkben van a munkatár- } \\
\text { sak között összetartozási érzés. }\end{array}$ & 1 & 4 & 1,80 & 0,741 \\
\hline (A) & $\begin{array}{l}\text { A tanulókhoz személytelen kapcsolatok } \\
\text { füzik a kollégákat. }\end{array}$ & 1 & 5 & 1,62 & 0,849 \\
\hline (A) & A mi intézményünk gyermekközpontú. & 1 & 5 & 3,23 & 1,199 \\
\hline (A) & $\begin{array}{l}\text { Határozottabb arculatot kellene adni } \\
\text { az intézménynek. }\end{array}$ & 2 & 5 & 4,73 & 0,544 \\
\hline (A) & $\begin{array}{l}\text { Pedagógusaink sok gondot fordítanak } \\
\text { a tanulók fegyelmezett magatartására. }\end{array}$ & 2 & 5 & 4,21 & 0,765 \\
\hline (B) & $\begin{array}{l}\text { Az órarenddel kapcsolatos kéréseimet } \\
\text { teljesítik. }\end{array}$ & 1 & 5 & 4,14 & 0,840 \\
\hline (B) & $\begin{array}{l}\text { A kollégák nem adják tovább egymásnak } \\
\text { a szakmai információkat. }\end{array}$ & 1 & 5 & 2,21 & 0,970 \\
\hline (B) & $\begin{array}{l}\text { Nagy önállósággal végezhetem } \\
\text { a munkámat. }\end{array}$ & 1 & 5 & 3,46 & 1,020 \\
\hline (B) & $\begin{array}{l}\text { Az iskolavezetés döntéseibe senkinek } \\
\text { nincs beleszólása. }\end{array}$ & 2 & 5 & 4,25 & 0,849 \\
\hline (M) & Szívesen tanítok. & 1 & 5 & 3,41 & 1,040 \\
\hline$(\mathrm{M})$ & Alig várom az utolsó tanítási óra végét. & 1 & 5 & 2,93 & 1,086 \\
\hline$(\mathrm{M})$ & A tanítás számomra hivatás. & 1 & 5 & 3,85 & 0,852 \\
\hline$(\mathrm{M})$ & A tanulókat semmi nem érdekli. & 2 & 5 & 3,87 & 0,762 \\
\hline
\end{tabular}




\begin{tabular}{|c|l|c|c|c|c|}
\hline $\begin{array}{c}\text { Alskála } \\
\text { betüjele }\end{array}$ & Állítások & Min. & Max. & Átlag & Szórás \\
\hline (V) & $\begin{array}{l}\text { Értekezleteken elmondhatom a személyes } \\
\text { véleményemet anélkül, hogy következmé- } \\
\text { nyektől kellene tartanom. }\end{array}$ & 1 & 5 & 3,54 & 0,988 \\
\hline (V) & $\begin{array}{l}\text { Tudomásom van minden lényeges dolog- } \\
\text { ról, ami az intézményben történik. }\end{array}$ & 1 & 5 & 3,29 & 0,914 \\
\hline (V) & $\begin{array}{l}\text { A mi iskolánkban a tanárok véleménye is } \\
\text { számít a fejlesztések tervezésekor. }\end{array}$ & 1 & 5 & 3,82 & 1,040 \\
\hline (V) & Az iskolavezetés elismeri a munkámat. & 1 & 5 & 2,62 & 1,249 \\
\hline & A munkahelyi klímát javítani kellene. & 1 & 5 & 3,74 & 0,958 \\
\hline & Lehetségesnek látom a klíma javítását. & 1 & 4 & 1,83 & 0,849 \\
\hline
\end{tabular}

5.3. táblázat: Az 1. sz. tanári kérdőív 7. kérdése 26 állításának ötfokú skálán történő megítélésére adott válaszok minimuma, maximuma, átlaga és szórása $(\mathrm{N}=125)$

A legerősebben megjelenő vélemény a válaszadó pedagógusok körében, hogy határozottabb arculatot kellene adni az intézménynek (átlag $=4,73$ szórás $=0,544)$ (3. táblázat). Ez megerősíti a korábbi általunk megadott értékek közötti választás eredményét, amely szerint „A közös teljesítmények kiemelését, elismerését” fontosnak tartják a pedagógusok.

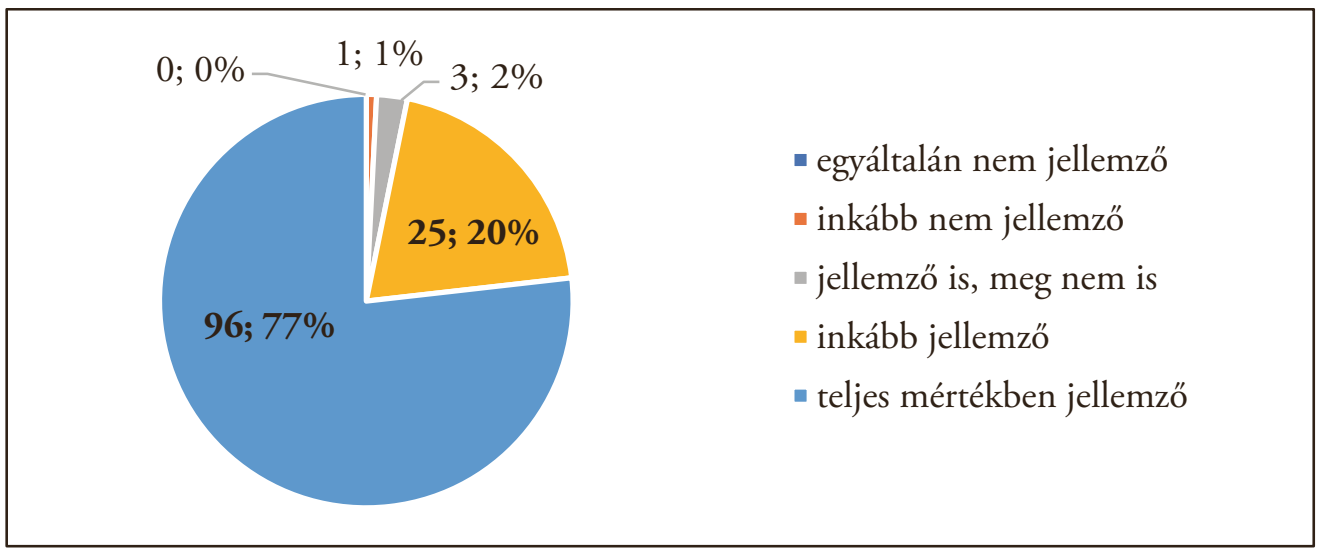

5. 6. ábra: A „Határozottabb arculatot kellene adni az intézménynek” állítás megítélésére adott tanári válaszok abszolút és relatív gyakorisági megoszlása $(\mathrm{N}=125)$

A válaszadók 97\%-a teljes mértékben jellemzőnek és inkább jellemzőnek tartotta ezt az állítást (6. ábra). Ez mindenképpen arra utal, hogy az iskola pozitív képe a külvilág irányában a pedagógiai munka elismertségének egyik nagyon fontos feltétele a válaszadók 
szerint. Ez összhangban áll azzal az eredménnyel, hogy a pedagógusok igen magasra értékelik szakmai tudásukat, és fontosnak tartják a más iskoláknak való példamutatást (lásd 8. fejezet).

Az ötfokozatú skála alapján jónak tekinthető átlagok a Kollégákkal való viszonyt leíró kategóriák esetében („Szívesen veszek részt a munkahelyi összejöveteleken” - átlag = 4,06; „Megbeszélem a kollégákkal a tanítással kapcsolatos problémáimat” - átlag = 4,07; „Minden kollégával tudok együtt dolgozni” - átlag = 3,97) arra utalnak, hogy az emberi kapcsolatok, az őszinte érdeklődés egymás iránt a pedagógusok többsége számára a pedagógiai klíma alakulásában nagyon fontos szerepet játszik. Ugyancsak e klíma alapvető építőköve a tanulókkal való jó személyes kapcsolat („A tanulókhoz személytelen kapcsolatok füzik a kollégákat” - átlag = 1,61). E megállapítások összhangban állnak az általunk megadott értékek rangsorolásánál született eredményekkel, vagyis az egyik legmeghatározóbb érték az iskolában az „Ösztönzés és lelkesítés a kényszer helyett”.

Ha a Pedagógiai Klíma Percepció teszt hat kérdéskörére vonatkozó kérdéscsoportokat vizsgáljuk, akkor megállapítható, hogy a pedagógusok kommunikációs kapcsolatai jónak tekinthetők, bár „A tanáriban jókat szoktunk beszélgetni” kategória vonatkozásában viszonylag alacsony átlagérték (átlag $=2,14$ ) született, és ebben a kategóriában a két épület között szignifikáns eltérés mutatható ki $(\mathrm{p}=0,042)$.

A kollégákhoz való viszony esetében „A mi intézményünkben van a munkatársak között összetartozási érzés” (átlag = 1,80) alacsony értéke és a „Hiányzik a bizalom a kollégák között” (átlag = 3,41) viszonylag magas értéke megerősítik egymást. A viszonylag alacsony értékek egyik oka lehet, hogy a „Néhány kollégát alig ismerek” kategória (átlag = 3,98) igen magas értékelést kapott. Ezeket az eredményeket érdemes összevetni a 4. fejezet megállapításaival, amely a pedagógusok az iskolába mint tanuló szervezetbe való bevonódását vizsgálja.

Az arculat esetében már az előbbiekben beszéltünk arról, hogy ebben a kérdéskörben született az egyik legmagasabb átlag, amely szerint a pedagógusok elismerésszükséglete elsősorban az iskola pozitív külső képe által történő megjelenítés segítségével elégíthető ki, ugyanakkor meg kell említenünk a kérdéscsoport legalacsonyabbra értékelt kategóriáját, amely szerint „A mi intézményünk gyermekközpontú” (átlag = 3,23) csak közepes szintű megítélést kapott: ez az iskola pedagógusainak hozzáállásáról kialakult képet árnyalja, és összefüggésben áll az általunk megadott értékválasztás eredményével, vagyis hogy „Az egyéni fejlődési ütem figyelembevétele” nem kifejezetten meghatározó érték a pedagógusok szerint.

A beleszólás (hogyan ítélik meg a pedagógusok azt, hogy szavuknak milyen súlya van, és hogy mennyire adottak az autonómiaszükséglet feltételei) tekintetében elmondható, hogy a kisebb kérések („Az órarenddel kapcsolatos kéréseimet teljesítik” - átlag = 4,14) teljesítésre kerülnek, míg a szakmai autonómia („Nagy önállósággal végezhetem a munkámat” - átlag $=3,46)$ és a vezetői szintű döntésekben a pedagógusok véleményének figyelembevétele („Az 
iskolavezetés döntéseibe senkinek nincs beleszólása” - átlag = 4,25), a válaszadók szerint nem kap kellő figyelmet (vö. 8. fejezet).

A munkához való viszony esetében elmondható, hogy eredményeink szerint a pedagógusok elhivatottnak érzik magukat a munkájuk iránt („A tanítás számomra hivatás” - átlag = 3,85), viszont a "Szívesen tanítok” (átlag = 3,41) és „A tanulókat semmi nem érdekli” (átlag $=3,87$ ) kategóriák értékei azt jelzik, hogy az önérvényesités és az önkifejezés igényeinek kielégülését akadályozza a tanulók alacsony motivációja.

Ami a vezetési stílus megitélését illeti, a pedagógusok szerint a vezetés elsősorban a fejlesztések esetén kéri ki a pedagógusok véleményét („A mi iskolánkban a tanárok véleménye is számít a fejlesztések tervezésekor" - átlag = 3,82), ugyanakkor a pedagógusok munkájának elismerése („Az iskolavezetés elismeri a munkámat” - átlag = 2,62) területén a pedagógusok értékelési szükségletei nem mindig kerülnek kielégítésre.

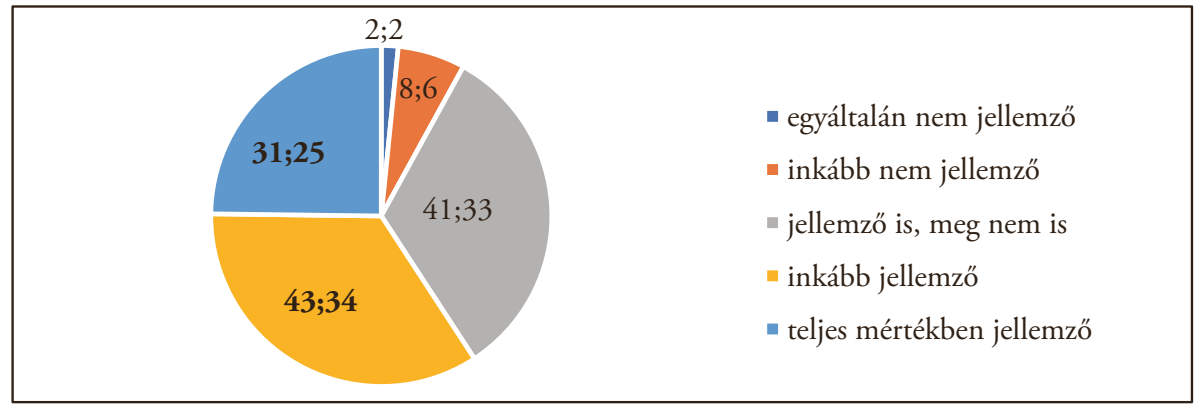

\section{7. ábra: „A munkahelyi klímát javítani kellene” állítás megítélésére adott tanári válaszok abszolút és relatív gyakorisági megoszlása $(\mathrm{N}=125)$}

Azt, hogy a munkahelyi klímát javítani kellene (átlag = 3,74), a válaszadók több mint fele (teljes mértékben jellemző, inkább $=59 \%$ ) jelölte meg (7. ábra). A válaszadók egy kicsivel több mint egyharmada (33\%) azonban erre a kérdésre nem tudott határozott választ adni.

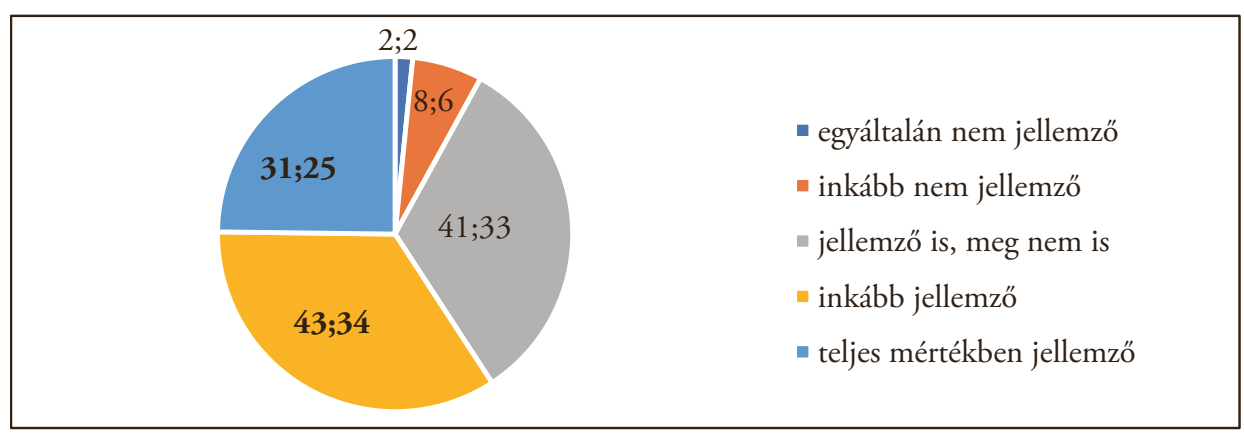

5.8. ábra: A „Lehetségesnek látom a klíma javítását” állítás megítélésére adott tanári válaszok abszolút és relatív gyakorisági megoszlása $(\mathrm{N}=125)$ 
Arra is rákérdeztünk, hogy a pedagógusok mennyire látják lehetségesnek javítani a munkahelyi klímát. Az előzőekkel megegyező arányú válaszok születtek minden kategóriában (8. ábra).

\subsection{Az iskolai légkör jellemzői a diákok válaszai alapján}

Mint ahogy a pedagógusoknál, úgy a diákok esetében is kíváncsiak voltunk arra, hogy hogyan ítélik meg iskolájukat, annak légkörét.

\begin{tabular}{|l|c|c|c|c|}
\hline & Átlag & Szórás & Minimum & Maximum \\
\hline közösségi & 4,05 & 0,923 & 1 & 5 \\
\hline fejlödésre ösztönzö & 3,94 & 0,988 & 1 & 5 \\
\hline nyitott a külvilágra & 3,92 & 0,957 & 1 & 5 \\
\hline támogató & 3,84 & 0,988 & 1 & 5 \\
\hline jól irányított & 3,73 & 1,091 & 1 & 5 \\
\hline izgalmas, érdekes & 3,53 & 1,075 & 1 & 5 \\
\hline demokratikus & 3,33 & 1,095 & 1 & 5 \\
\hline szórakoztató, bulis & 3,00 & 1,165 & 1 & 5 \\
\hline korlátozó & 2,99 & 1,184 & 1 & 5 \\
\hline folyton változó & 2,77 & 1,044 & 1 & 5 \\
\hline régimódi & 2,05 & 1,048 & 1 & 5 \\
\hline rideg & 1,83 & 1,079 & 1 & 5 \\
\hline
\end{tabular}

5.4. táblázat: $A$ „Szerinted mennyire jellemzőek az alábbi tulajdonságok az iskolára?” kérdésre adott válaszok átlaga, szórása, minimuma és maximuma $(\mathrm{N}=255)$

A „Szerinted mennyire jellemzőek az alábbi tulajdonságok az iskolára?” kérdésre adott válaszok azt jelzik, hogy a felső tagozatos és középiskolai diákok szerint elsősorban a közösségi jelleg (átlag = 4,05; szórás = 0,923), a fejlődésre való ösztönzés (átlag = 3,94; szórás $=0,988$ ) és a külvilágra való nyitottság (átlag $=3,92$; szórás $=0,957$ ) a legjellemzőbb tulajdonsága a gyakorlóiskolának (4. táblázat). Ez összhangban áll a pedagógusok véleményével, amely szerint az egyik legjellemzőbb tulajdonsága az iskolának a külvilágra való nyitottság (átlag $=4,23$ ). 


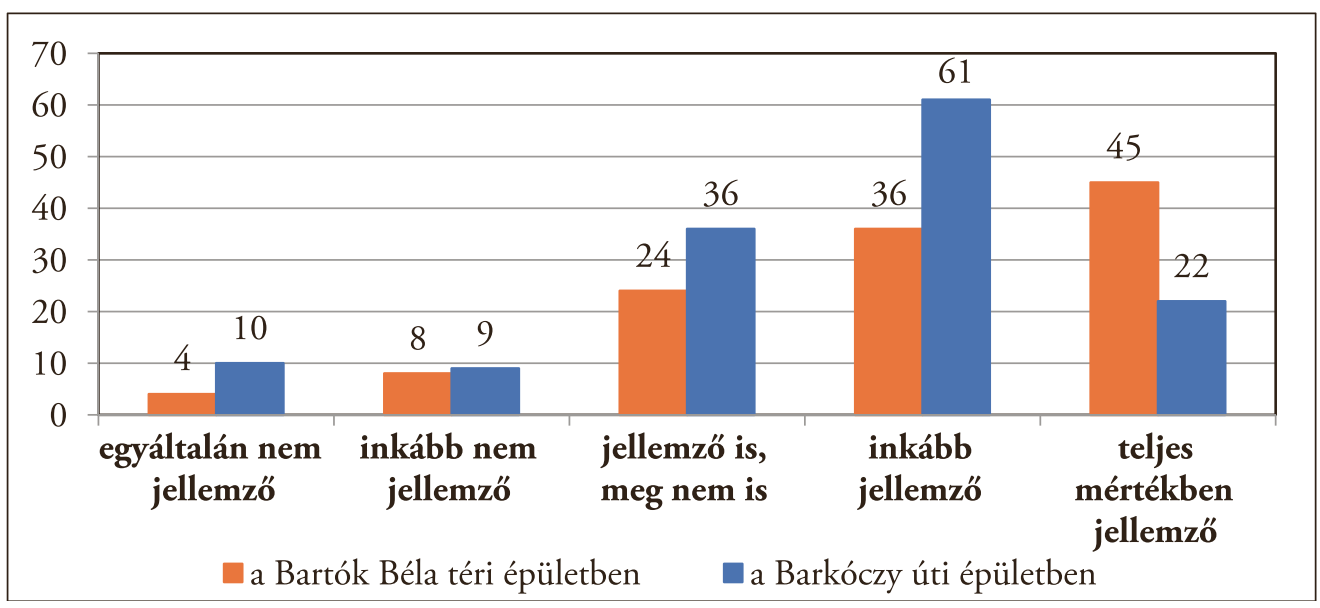

5.9. ábra: Az iskola „jól irányítottságának” megítélésére adott válaszok abszolút gyakorisági megoszlása a két épületben tanuló diákok csoportjaiban

$$
(\mathbf{p}=0,001 ; \mathrm{N}=255)
$$

Az eredmények szerint ugyanakkor néhány jellemző tekintetében szignifikáns különbség mutatkozik a két épületben tanuló diákok válaszaiban (9. ábra). A kérdőívet kitöltő, a Bartók téri épületben tanuló diákoknak ugyanis nagyobb része, 38,5 százaléka (45 fó) véli úgy, hogy a „jól irányítottság” teljes mértékben jellemző az iskolára, mint a Barkóczy úti épület diákjai (15,9\%; 22 fö; p = 0,001).

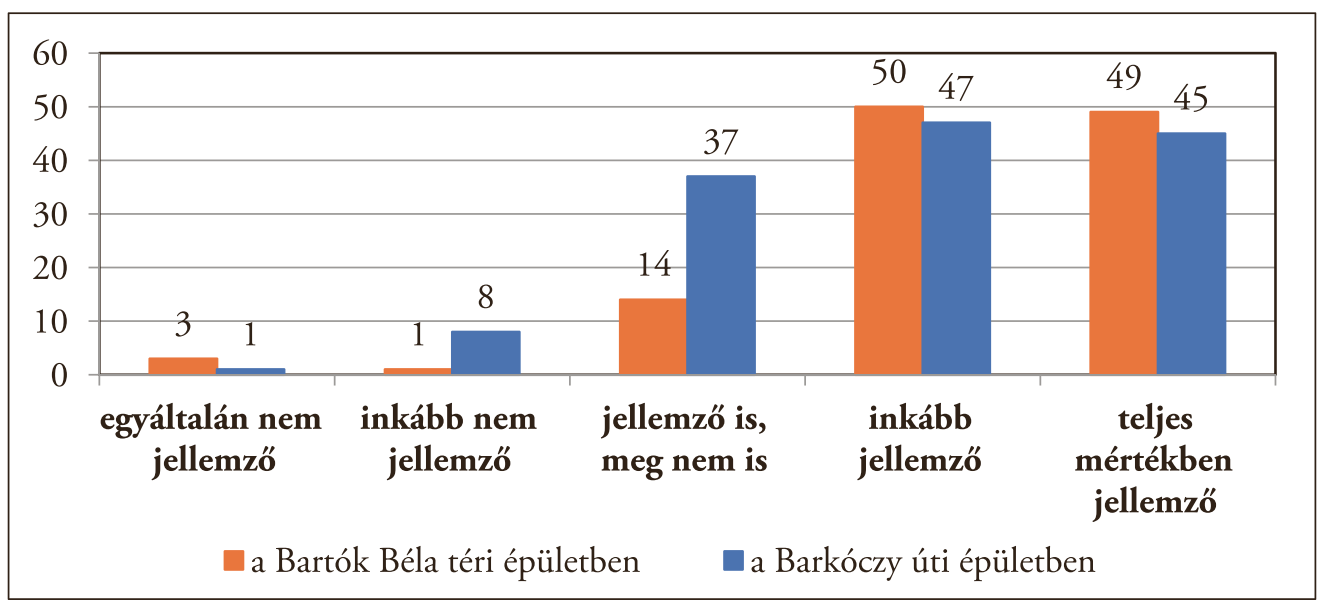

5.10. ábra: Az iskola „közösségi” jellegének megítélésére adott válaszok abszolút gyakorisági megoszlása a két épületben tanuló diákok csoportjaiban ( $\mathrm{p}=\mathbf{0 , 0 0 4}$;

$$
\mathrm{N}=255)
$$


Hasonlóképp igaz, hogy a Bartók téri iskola diákjai pozitívabban ítélik meg az iskola közösségi jellegét, mint a Barkóczy úti diákok (10. ábra): a válaszadó Bartók téri diákoknak összesen 84,6 százaléka (99 fó), míg a válaszadó Barkóczy úti diákoknak mindössze 66,7 százaléka (92 fö) vélekedik úgy, hogy az iskolára a közösségiesség jellemző ( $\mathrm{p}=0,004)$.

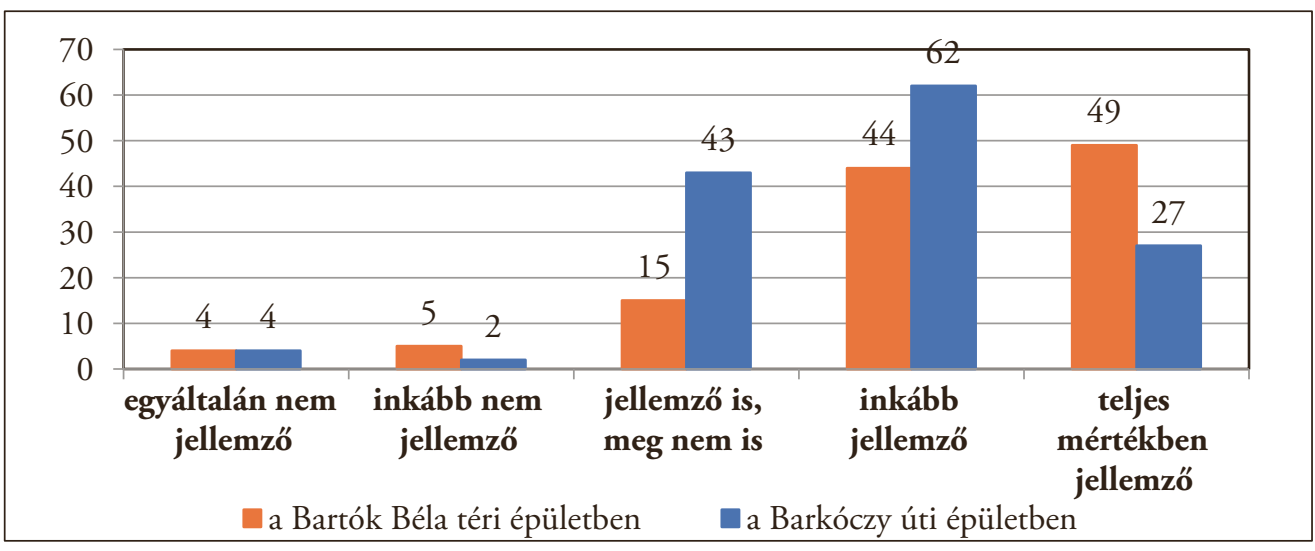

5.11. ábra: Az iskola „külvilágra való nyitottságának” megítélésére adott válaszok abszolút gyakorisági megoszlása a két épületben tanuló diákok csoportjaiban ( $<0,001 ; \mathrm{N}=255)$

Szintén a Bartók téri diákok ítélik meg pozitívabban az iskolájuk külvilágra való nyitottságát (11. ábra): ezt a tulajdonságot ugyanis a Bartók téri épületben tanulók 79,5 százaléka (93 fó) ítéli jellemzőnek, míg a Barkóczy úti épület diákjai közül csak 64,5 (89 fó) százalék vélekedik hasonlóképp ( $\mathrm{p}<0,001)$.

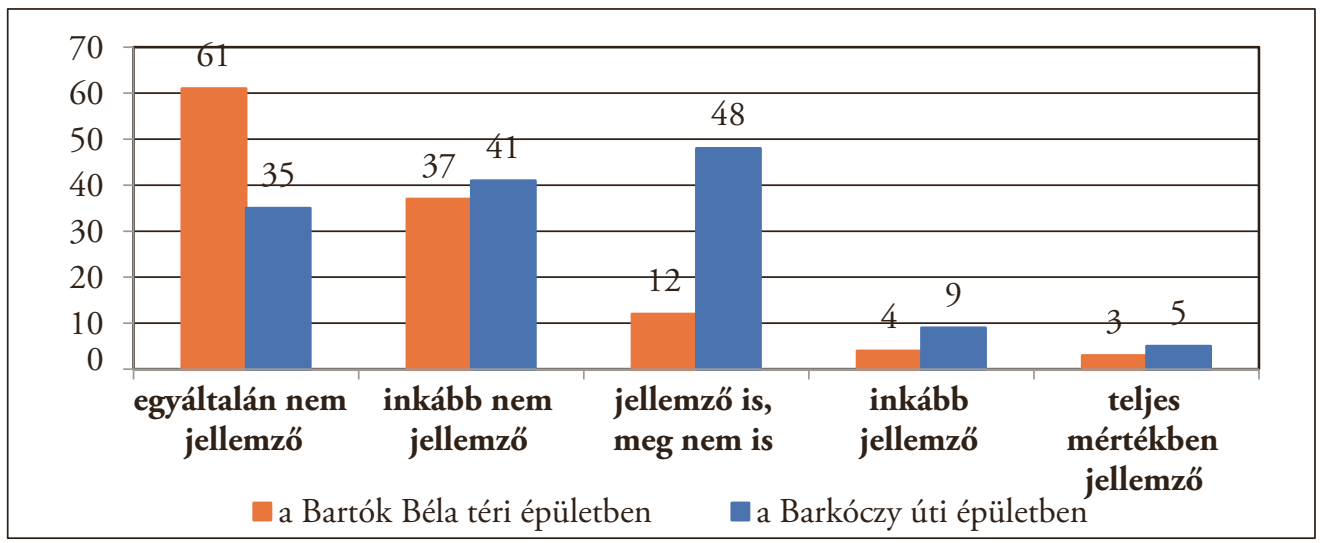

5.12. ábra: Az iskola „régimódiságának” megítélésére adott válaszok abszolút gyakorisági megoszlása a két épületben tanuló diákok csoportjaiban

$$
(\mathrm{p}<0,001 ; \mathrm{N}=255)
$$




\section{Végül az iskola régimódisága a Bartók téren tanuló diákok szerint kevésbé jellemző}

iskolájukra, mint a Barkóczy téri épület diákjai szerint (12. ábra): a kérdőívet kitöltő Bartók téri diákok 83,8 százaléka (93 fö) szerint iskolájukra nem jellemző az, hogy régimódi lenne, míg a Barkóczy úti diákoknak csak 55,1 százaléka (76 fó) vélekedik így ( $<$ < 0,001).

A felső tagozatos és középiskolás diákoknak szóló kérdőívünk 8. sz. kérdésében a Kreatív Iskolai Klíma Kérdőív (Péter-Szarka, Tímár és Balázs, 2015) kérdéseire kellett válaszolniuk a diákoknak. Az általunk kiválasztott 20 állításra, amelyek az iskolai kreatív klíma megítélését állították középpontba, az alábbi eredmények születtek.

\begin{tabular}{|c|c|c|c|}
\hline $\begin{array}{l}\text { Alskála } \\
\text { betüjele }\end{array}$ & Állítások & Átlag & Szórás \\
\hline Cs & Az osztályunkban erős az összetartás. & 3,68 & 1,132 \\
\hline Cs & Az osztályom tagjai kedvelik egymást. & 3,67 & 1,016 \\
\hline Cs & Az osztályunk képtelen az együttmüködésre. & 2,17 & 1,137 \\
\hline Cs & $\begin{array}{l}\text { Sok személyes konfliktus van az osztálytársaim } \\
\text { között. }\end{array}$ & 2,55 & 1,121 \\
\hline Ny & $\begin{array}{l}\text { A tanárok biztatnak minket új megoldások } \\
\text { keresésére. }\end{array}$ & 3,61 & 1,131 \\
\hline Ny & $\begin{array}{l}\text { Bátorítanak arra, hogy hibázás után is próbál- } \\
\text { jak megoldást keresni a feladatokra. }\end{array}$ & 3,75 & 1,086 \\
\hline $\mathrm{Ny}$ & A tanáraim nyitottak az új ötletekre. & 3,52 & 1,086 \\
\hline $\mathrm{Ny}$ & $\begin{array}{l}\text { Mindig megpróbáljuk a dolgokat több néző- } \\
\text { pontból megvizsgálni. }\end{array}$ & 3,30 & 1,018 \\
\hline $\mathrm{B}$ & $\begin{array}{l}\text { Van lehetőségem arra, hogy elmondjam az órán } \\
\text { a véleményemet. }\end{array}$ & 3,75 & 1,079 \\
\hline $\mathrm{B}$ & $\begin{array}{l}\text { Szabadon felszólalhatok, vitába bonyolódhatok, } \\
\text { ha valamivel nem értek egyet. }\end{array}$ & 3,08 & 1,243 \\
\hline $\mathrm{B}$ & $\begin{array}{l}\text { Van lehetőségünk arra, hogy az órai munka } \\
\text { során önálló döntéseket hozzunk. }\end{array}$ & 3,18 & 1,049 \\
\hline $\mathrm{B}$ & $\begin{array}{l}\text { A tanárokat érdekli, hogy a diákok mit gondol- } \\
\text { nak egy témáról. }\end{array}$ & 3,30 & 1,108 \\
\hline $\mathrm{Ki}$ & $\begin{array}{l}\text { Az iskolában tanultakra nincs szükség } \\
\text { a hétköznapokban. }\end{array}$ & 2,72 & 1,176 \\
\hline $\mathrm{Ki}$ & $\begin{array}{l}\text { Jól meghatározott céljaim vannak a tanulmá- } \\
\text { nyaimmal kapcsolatban. }\end{array}$ & 3,74 & 1,117 \\
\hline $\mathrm{Ki}$ & Az órai feladatok nem kötik le a figyelmemet. & 2,78 & 1,029 \\
\hline $\mathrm{Ki}$ & $\begin{array}{l}\text { Úgy érzem, fontos dolgokat tanulunk } \\
\text { az iskolában. }\end{array}$ & 3,25 & 1,032 \\
\hline
\end{tabular}




\begin{tabular}{|c|l|c|c|}
\hline $\begin{array}{c}\text { Alskála } \\
\text { betüjele }\end{array}$ & Állítások & Átlag & Szórás \\
\hline Ko & $\begin{array}{l}\text { Gyakran vagyunk lemaradva a tanulásban, } \\
\text { ezért sietnünk kell az anyaggal. }\end{array}$ & 2,87 & 1,111 \\
\hline Ko & $\begin{array}{l}\text { Nem engedhetjük meg az órán magunknak, } \\
\text { hogy humoros megjegyzéseket tegyünk. }\end{array}$ & 2,67 & 1,117 \\
\hline Ko & $\begin{array}{l}\text { Pontosan úgy kell végrehajtanunk a feladatokat, } \\
\text { ahogyan azt a tanár akarja. }\end{array}$ & 3,44 & 1,002 \\
\hline Ko & $\begin{array}{l}\text { Az órákon nincs idónk a feladatokat saját } \\
\text { tempónkban megoldani. }\end{array}$ & 3,02 & 1,120 \\
\hline
\end{tabular}

5.5. táblázat: A felső tagozatos és középiskolás diákoknak szóló kérdőív 8. kérdése 1-20. állításának ötfokú skálán történő megítélésére adott válaszok átlaga és szórása $(\mathrm{N}=255)$

A legmagasabb átlagokat a „Bátorítanak arra, hogy hibázás után is próbáljak megoldást keresni a feladatokra” (átlag = 3,75), a „Van lehetőségem arra, hogy elmondjam az órán a véleményemet” (átlag $=3,75$ ) és a „Jól meghatározott céljaim vannak a tanulmányaimmal kapcsolatban” (átlag = 3,74) állítások kapták (5. táblázat).

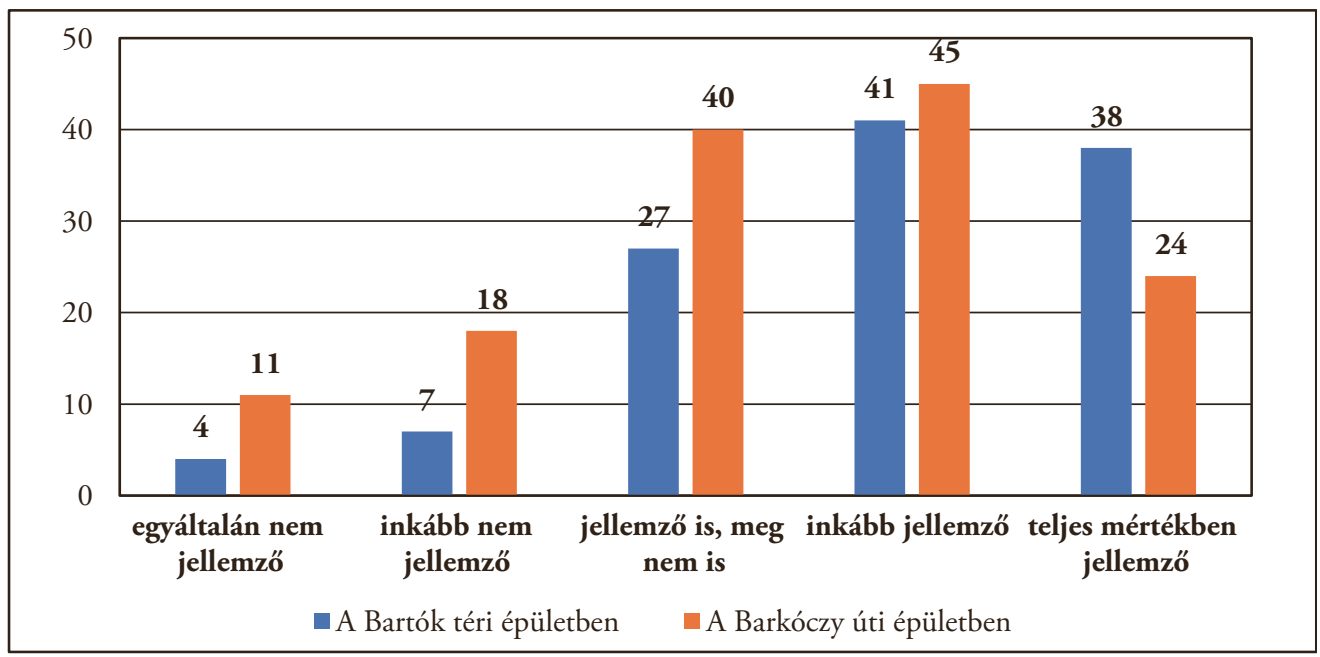

5. 13. ábra: „A tanárok biztatnak minket új megoldások keresésére” állítás megítélésére adott válaszok abszolút gyakorisági megoszlása a két épületben tanuló diákok csoportjaiban ( $\mathrm{p}=0,015 ; \mathrm{N}=255$ )

2 A Kreatív Iskolai Klíma Kérdőívnek (Péter-Szarka, Tímár és Balázs, 2015) a kutatáshoz kiválasztott 20 iteme. 
A tapasztalatokra, újdonságokra való nyitottság alskáláit vizsgálva megállapíthatjuk, hogy „A tanárok biztatnak minket új megoldások keresésére” (13. ábra) és a „Bátorítanak arra, hogy hibázás után is próbáljak megoldást keresni a feladatokra" (14. ábra) kategóriák esetében hasonló a válaszok eloszlása a Bartók téri és a Barkóczy úti épület tanulóinak válaszait elemezve.

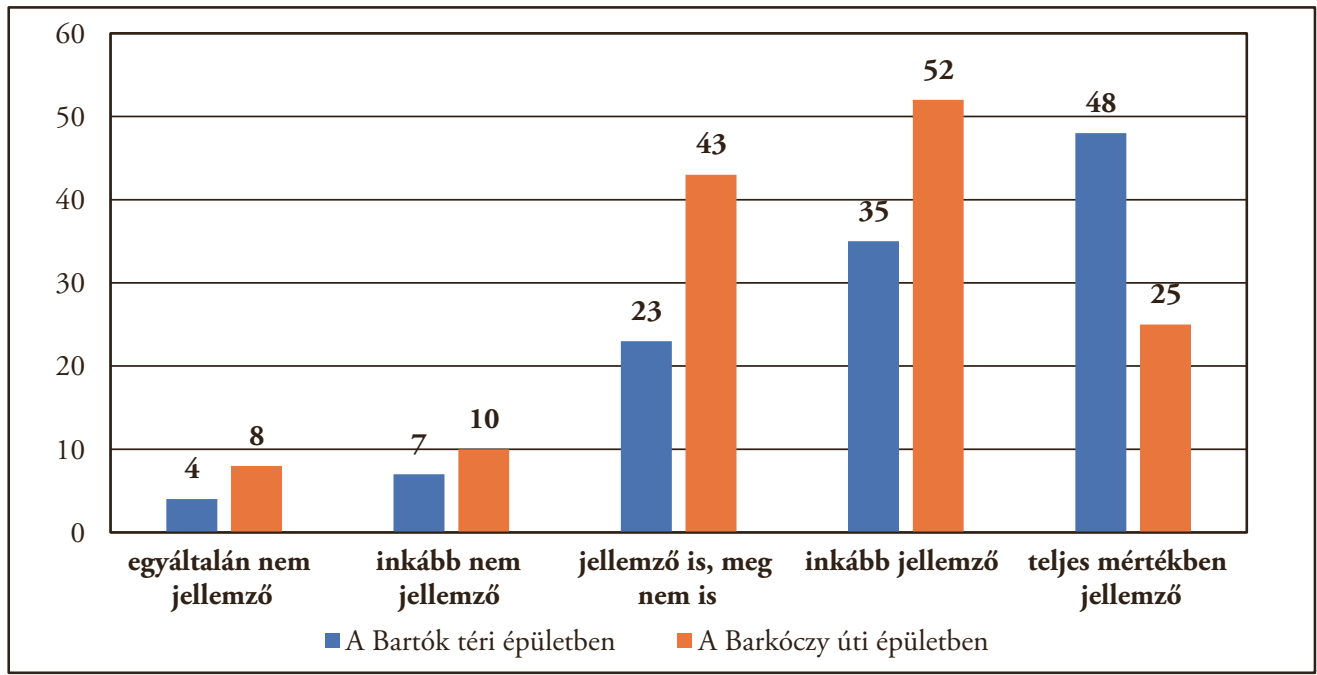

\subsection{4. ábra: A „Bátorítanak arra, hogy hibázás után is próbáljak megoldást} keresni a feladatokra" állítás megítélésére adott válaszok abszolút gyakorisági megoszlása a két épületben tanuló diákok csoportjaiban ( $\mathrm{p}=0,002 ; \mathrm{N}=255)$

Mindkét kérdés esetén az inkább jellemző válaszok a meghatározók, és a Barkóczy úti épület tanulói megítélése kedvezőbb, ugyanakkor a „Bátorítanak arra, hogy hibázás után is próbáljak megoldást keresni a feladatokra" kategóriánál nagyobbak az eltérések a két épület vonatkozásában (Bartók téri épület $=35$, Barkóczy úti épület $=52$ ).

A „Mindig megpróbáljuk a dolgokat több nézőpontból megvizsgálni” kategóriánál feltűnően alacsony a teljes mértékben jellemző válaszok aránya mindkét épületnél, az inkább jellemző választ a Bartók téren tanulók (megjelölte $=51$ ) többen választották, mint a Barkóczy úton tanulók (megjelölte $=35$ ). A másik érdekes eredmény, hogy a Barkóczy úti épület tanulói kimagasló arányban jelölték meg a jellemzö is, meg nem is választ (56fö) a Bartók téri épület tanulóihoz képest (36fö) (15. ábra). 


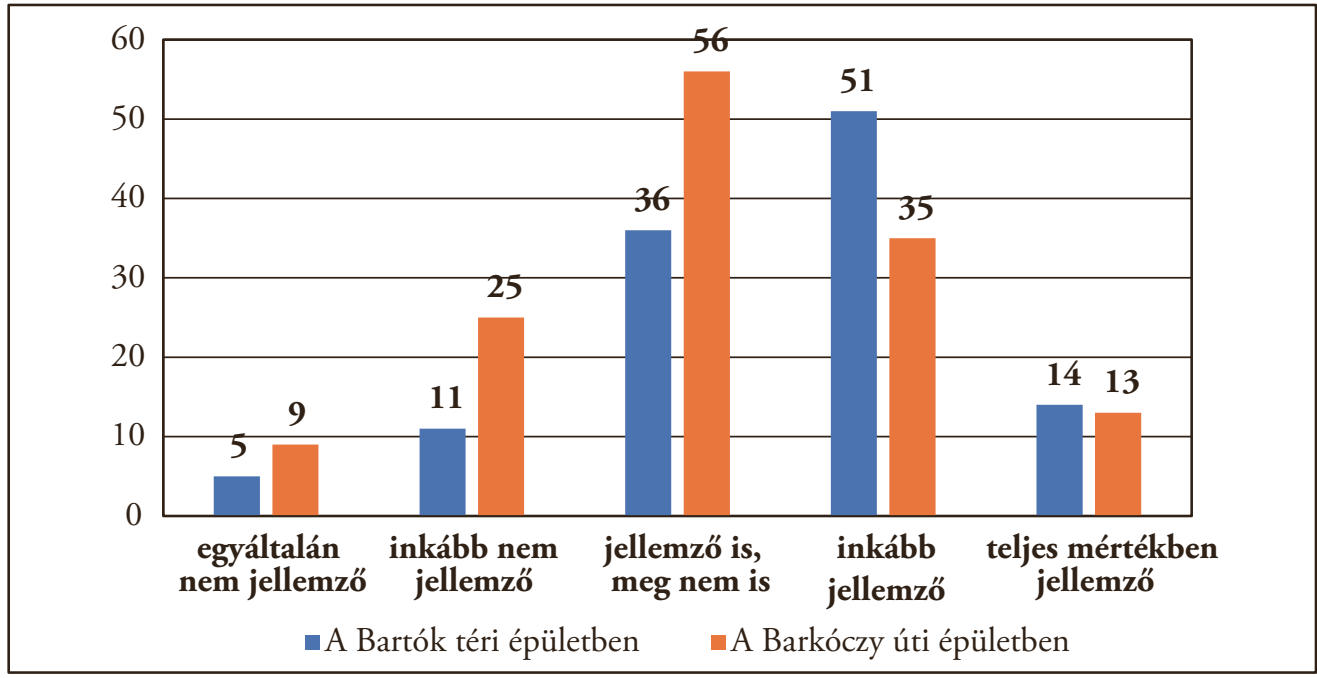

5.15. ábra: A „Mindig megpróbáljuk a dolgokat több nézőpontból megvizsgálni” állítás megítélésére adott válaszok abszolút gyakorisági megoszlása a két épületben tanuló diákok csoportjaiban ( $\mathrm{p}=0,015 ; \mathrm{N}=255)$

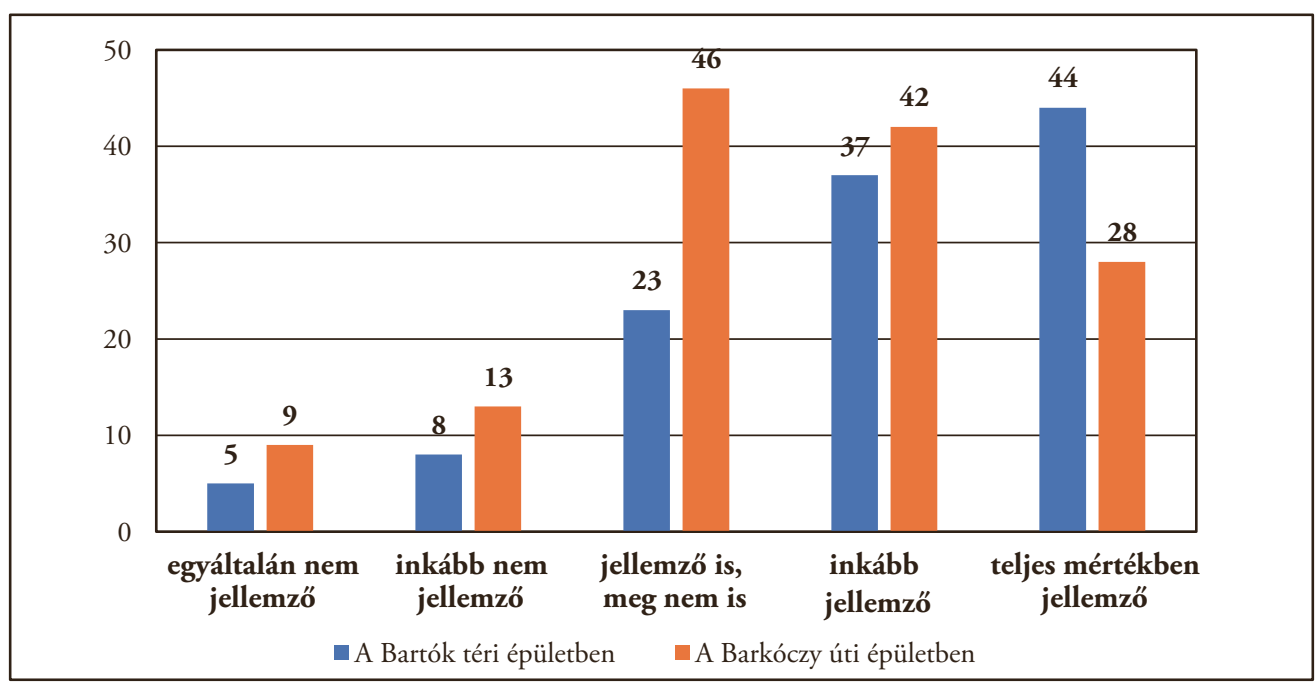

5.16. ábra: „Az osztályunkban erős az összetartás” állítás megítélésére adott válaszok abszolút gyakorisági megoszlása a két épületben tanuló diákok csoportjaiban ( $=0,016 ; \mathrm{N}=255$ )

A két épületben tanulók véleménye szerint a csoport alskálák esetében a csoportlégkör és a bizalom megítélésére vonatkozóan két kategóriánál hasonló a válaszok aránya. Az egyik „Az osztályunkban erős az összetartás” (16. ábra) és „Az osztályom tagjai kedvelik egymást” (17. ábra). 


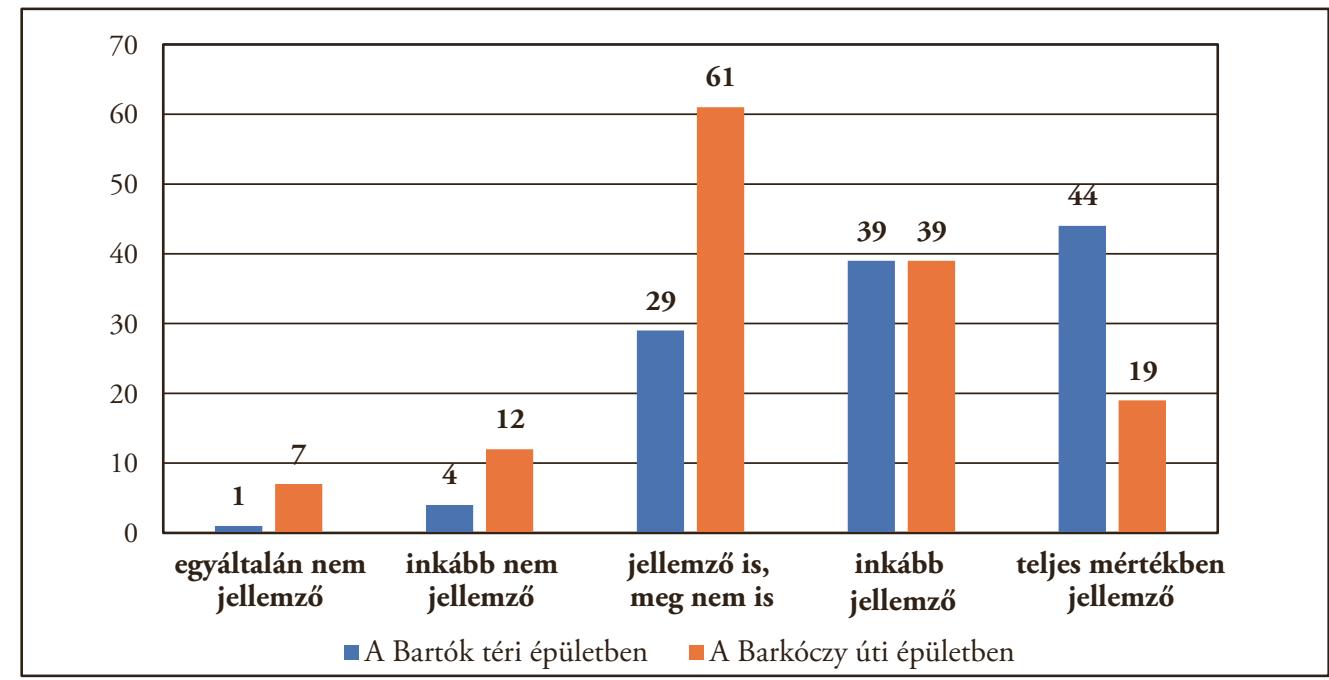

5.17. ábra: „Az osztályom tagjai kedvelik egymást” állítás megítélésére adott válaszok abszolút gyakorisági megoszlása a két épületben tanuló diákok csoportjaiban $(\mathrm{p}<0,001 ; \mathrm{N}=255)$

Az érdekesség ismét az, hogy a bizonytalan válaszadók aránya a Barkóczy úti épület esetében sokkal magasabb mindkét kategóriánál („Az osztályunkban erős az összetartás” - Barkóczy úti épület = 46 fo és „Az osztályom tagjai kedvelik egymást” - Barkóczy úti épület $=61$ fó) $(17 . a ́ b r a)$.

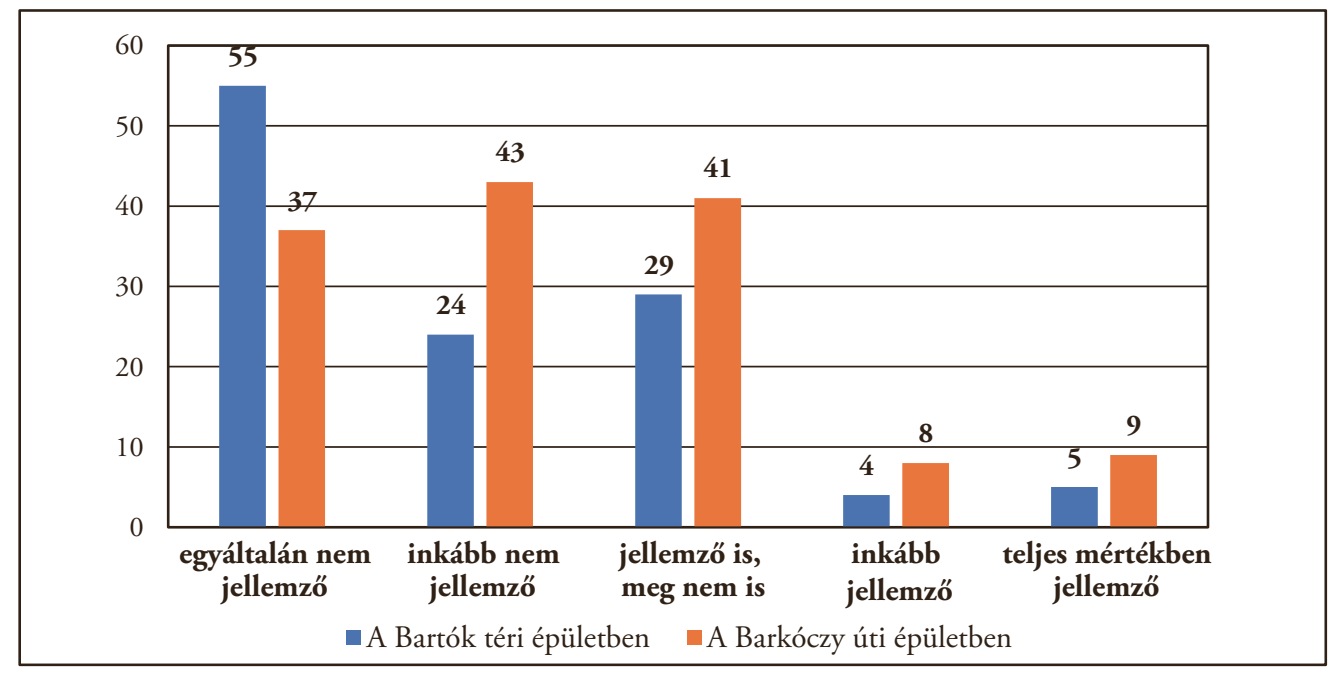

5.18. ábra: „Az osztályunk képtelen az együttmúködésre” állítás megítélésére adott válaszok abszolút gyakorisági megoszlása a két épületben tanuló diákok csoportjaiban ( $\mathrm{p}=\mathbf{0 , 0 1 9 ;} \mathrm{N}=255)$ 
Az osztályon belüli együttműködés megítélése esetében az egyáltalán nem jellemzö, inkább nem jellemző válaszok aránya a magasabb mindkét épület esetében, de a Barkóczy úti épület diákjainál magasabb a bizonytalan tanulók aránya (41fó; 30\%), mint a Bartók téri tanulóknál (29fó; 25\%) (18. ábra).

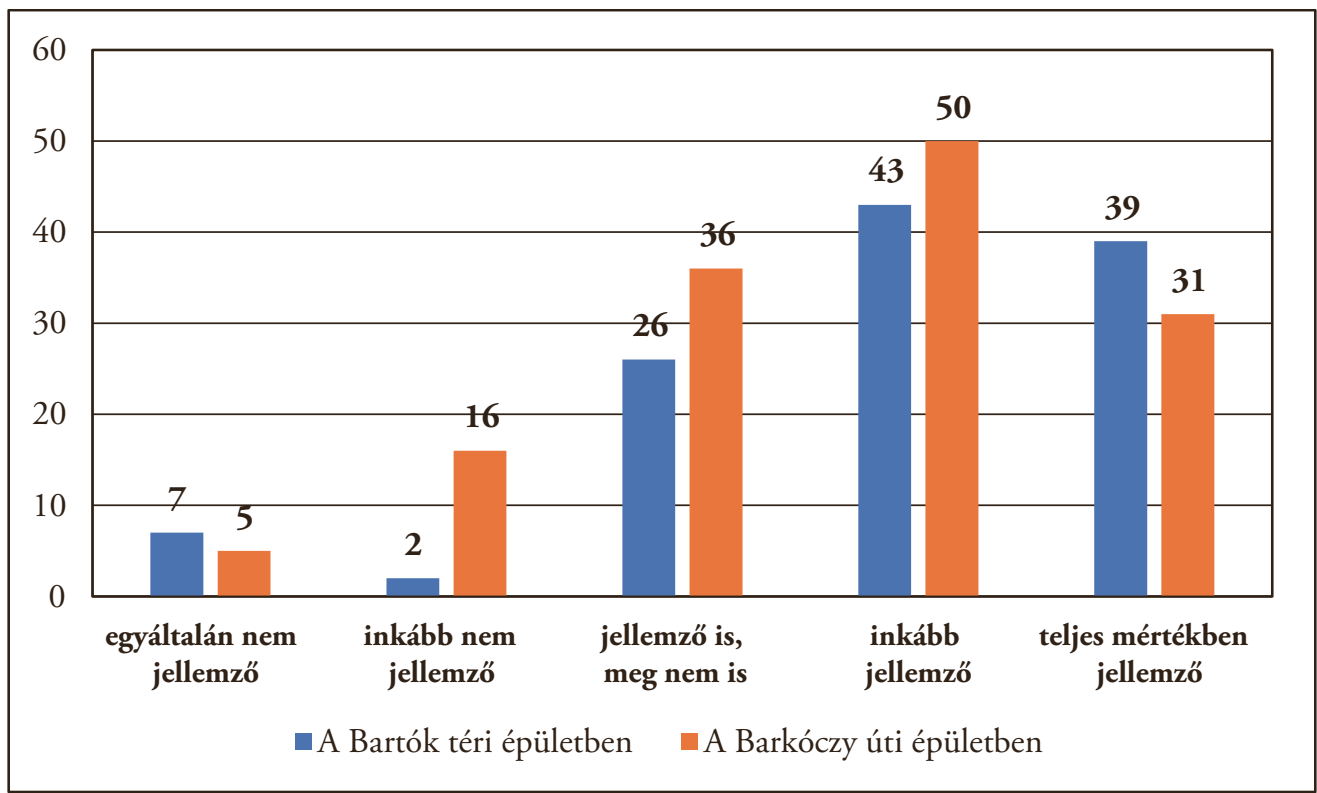

5.19. ábra: A „Van lehetőségem arra, hogy elmondjam az órán a véleményemet” állítás megítélésére adott válaszok abszolút gyakorisági megoszlása a két épületben tanuló diákok csoportjaiban ( $\mathrm{p}=0,013 ; \mathrm{N}=255)$

A bátorítási alskálánál, ahol az egyik legmagasabb átlag született („Van lehetőségem arra, hogy elmondjam az órán a véleményemet" - átlag = 3,75), az inkább jellemző válaszok dominálnak mindkét épületnél (Batók téri épület $=43$ fö, Barkóczy úti épület $=50$ fö) (19. ábra). 


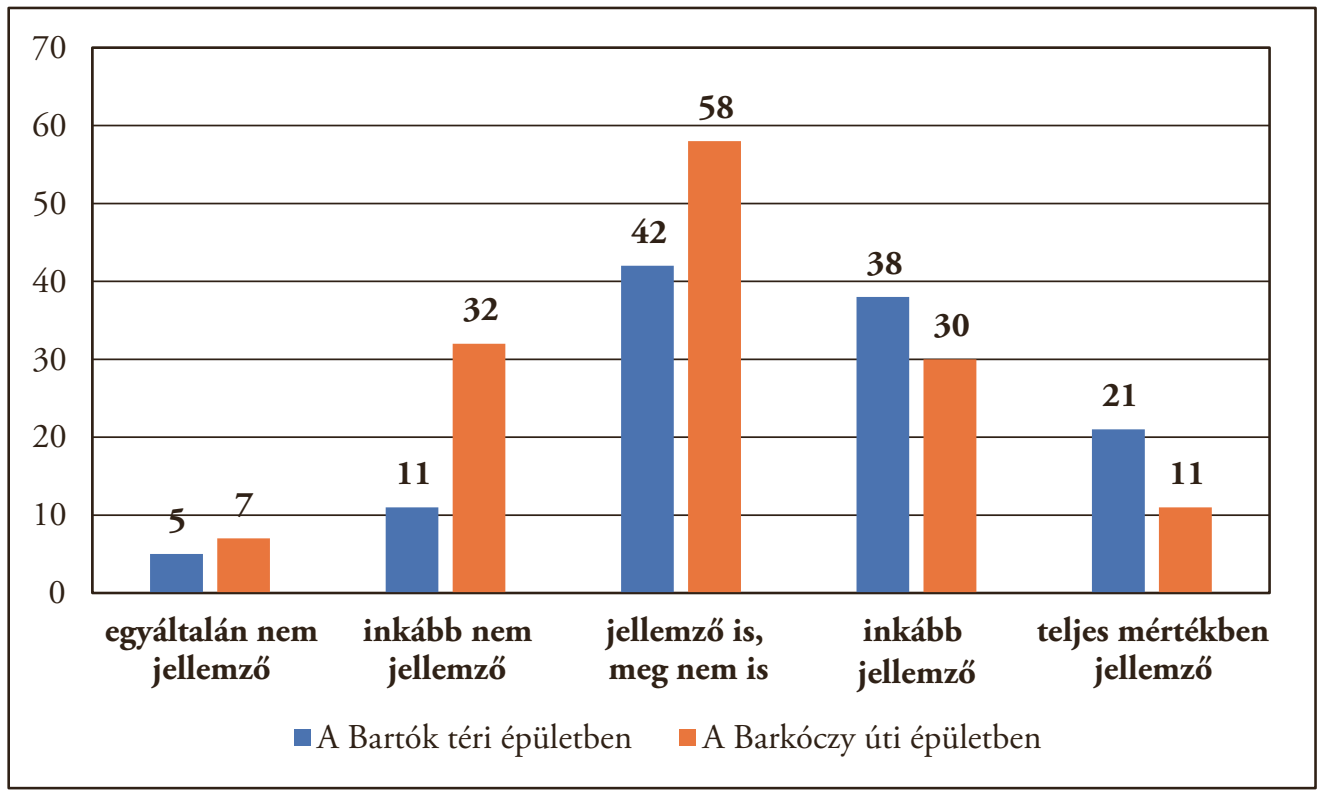

5.20. ábra: Az „Úgy érzem, fontos dolgokat tanulunk az iskolában” állítás megítélésére adott válaszok abszolút gyakorisági megoszlása a két épületben tanuló diákok csoportjaiban ( $\mathrm{p}=0,004 ; \mathrm{N}=255$ )

A kihívás alskála „Úgy érzem, fontos dolgokat tanulunk az iskolában” kategóriájánál a jellemző is, meg nem is válaszokat jelölték meg a tanulók a legtöbbször mindkét épületben (Bartók téri épület $=42$ fó, Barkóczy úti épület = 58 fó) (20. ábra). A kategóriára adott átlag (átlag = 3,25) és a válaszok ilyen arányú megoszlása arra utal, hogy a tanulók motiváltsága, a feladatok értelmességének megítélése vonatkozásában felmerül a további pedagógiai teendők szükségessége. E tekintetben is párhuzamot lehet vonni a tanulók és a pedagógusok nézetei között, hiszen maguk a pedagógusok is viszonylag alacsonyabb szintünek ítélték meg a tanulók motiváltságát (lásd. Pedagógiai Klíma Percepció teszt „A tanulókat semmi nem érdekli” - átlag = 3,87).

\subsection{Az iskolai légkör jellemzői a szülők válaszai alapján}

A gyakorlóiskolába járó diákok szüleinek szóló kérdőívben szintén szerepelt a fentebb említett kérdés, $s$ az eredmények szerint a szülők gyermekeikhez nagyon hasonlóan látják a gyakorlóiskola legfóbb tulajdonságait. 


\begin{tabular}{|l|c|c|c|c|}
\hline & Átlag & Szórás & Minimum & Maximum \\
\hline közösségi & 4,15 & 0,748 & 1 & 5 \\
\hline fejlödésre ösztönző & 3,98 & 0,855 & 1 & 5 \\
\hline nyitott a külvilágra & 4,06 & 0,794 & 1 & 5 \\
\hline támogató & 3,87 & 0,829 & 1 & 5 \\
\hline jól irányított & 3,88 & 0,911 & 1 & 5 \\
\hline izgalmas, érdekes & 3,82 & 0,894 & 1 & 5 \\
\hline demokratikus & 3,57 & 0,866 & 1 & 5 \\
\hline szórakoztató, bulis & 3,23 & 1,009 & 1 & 5 \\
\hline korlátozó & 2,48 & 0,953 & 1 & 5 \\
\hline folyton változó & 2,58 & 1,052 & 1 & 5 \\
\hline régimódi & 1,95 & 1,031 & 1 & 5 \\
\hline rideg & 1,61 & 0,843 & 1 & 5 \\
\hline
\end{tabular}

5.6. táblázat: Az „Ön szerint mennyire jellemzőek az alábbi tulajdonságok az iskolára?” kérdésre adott szülői válaszok átlaga, szórása, minimuma és maximuma $(\mathrm{N}=247)$

A szülők véleménye szerint (6. táblázat) a gyakorlóiskola elsősorban közösségi (átlag $=4,15$; szórás $=0,748$ ) színtér, de jellemző még rá az is, hogy nyitott a külvilágra (átlag = 4,06; szórás $=0,794$ ), és ösztönzi a fejlődést (átlag =3,98; szórás $=0,855$ ). Mind a jól irányítottság (átlag = 3,88), mind a demokratikus légkör vonatkozásában (átlag = 3,57) magasabbak az átlagok, mint a tanulók megítélése szerinti értékek. A szülők válaszaiban ugyanakkor nem mutatkoznak különbségek attól függően, hogy gyermekük melyik iskolaépületbe jár.

\section{5. Összegzés}

Ebben a tanulmányban az iskolai klíma vizsgálatát tűztük ki célul. Elemzésünk fókuszában a gyakorlóiskola pedagógusai, tanulói és szüleik nézetei álltak. A pedagógusok és a tanulók iskolai klímára vonatkozó véleményét saját szerkesztésű kérdésekkel és adaptált klímatesztek általunk kiválasztott kérdéseivel vizsgáltuk.

A pedagógusok túlnyomó többségének megítélése szerint az iskola mint iskolaközösség (diákok, pedagógusok, szülők, hallgatók, oktatók) jól működik. A két épület nevelőtestülete 
közötti együttműködést a pedagógusok több mint 50\%-a megfelelőnek tartja, de a tanárok több mint egyharmada vegyesen ítéli meg a kérdést. Eredményeink alapján elmondható, hogy az iskolát bemutató értékek közötti választásban kis eltérések mutathatók ki a pedagógusok nézeteiben, emiatt nincs igazán kiemelkedő érték a pedagógusok körében. A pedagógusok szerint az általunk felsoroltak közül elsősorban a külvilágra való nyitottság és a fejlődésre való ösztönzés a legjellemzőbb tulajdonsága a gyakorlóiskolának. A pedagógiai klíma tekintetében az iskola arculatának határozottabb megjelenítését tartják fontosnak a pedagógusok, ami összecseng azzal a véleményükkel, amely szerint a közös teljesítmények elismerése az egyik legmeghatározóbb érték számukra. A pedagógiai klímát a kérdőívet kitöltő pedagógusok véleménye szerint szükséges lenne javítani, de abban megosztottak, hogy ez egyáltalán lehetséges-e. Az iskola irányítottságával és demokratikus légkörével kapcsolatban a két telephely pedagógusainak válaszai között eltérések mutatkoznak: a Bartók téri épületben dolgozó pedagógusok elégedetlenebbek ezen a területen, mint a Barkóczy úti épületben dolgozók.

A tanulók véleménye szerint a közösségi jelleg, a fejlődésre való ösztönzés és a külvilágra való nyitottság a legjellemzőbb tulajdonsága a gyakorlóiskolának. Ez összhangban áll a pedagógusok véleményével, amely szerint az egyik legjellemzőbb tulajdonsága az iskolának a külvilágra való nyitottság. A kreatív klíma teszt eredményei alapján a bátorítás, a vélemény szabad megfogalmazása, valamint a tudatos tanulás (célok mentén) támogatása a leginkább jellemző vonásai a gyakorlóiskolának. Ugyanakkor a kihívások vonatkozásában nem minden esetben érzik úgy a tanulók, hogy fontos dolgokat tanulnak az iskolában; ezt erősítette meg a kategória közepes szintű értékelése és a határozatlan választ adók magas aránya is. Maguk a pedagógusok is érzik ezt a problémát, amelyet a Pedagógiai Percepció Klíma teszt tanulók motiváltságára vonatkozó kategóriájában született válaszok is megerősítenek. Az iskola irányítottságának megítélése kapcsán a pedagógusokkal ellentétben a Bartók téren tanuló diákok azok, akik jobbnak ítélik meg az iskola irányítottságát.

A szülők és gyermekeik megítélése az iskola klímájára vonatkozóan nagyon hasonló, hiszen a szülők is a közösségi létet, a külvilágra való nyitottságot és a fejlődésre való ösztönzést tartják az iskolai klíma legjellemzőbb tulajdonságainak. Összességében a szülők jobbnak ítélik meg az iskola irányítottságát, mint a gyermekeik, és válaszaikban sem mutathatók ki olyan fokú különbözőségek az épületek esetében, mint a diákoknál.

\section{Javaslatok}

Tekintettel arra, hogy az évtizedes egységesítési törekvés ellenére sem sikerült a pedagógusok körében teljes mértékben elfogadtatni, hogy a két iskola egységet képez, és hogy az egyes épületek közösségéhez való tartozás meglehetősen erős, meg kellene találni annak a módját, 
hogy a két egység lényegében önállóan tevékenykedjen, és csak egymás munkájának segítése érdekében működjön együtt. Azaz nagyobb épületenkénti autonómiára, az egyéni sajátosságok érvényesítésére kellene módot adni.

Fel kellene tárni, hogy az iskola értékeinek megítélésében miért mutatkozik lényeges különbség a két épület diákjainak válaszaiban. Ezt követően lehet megtenni a szükséges lépéseket a kedvezőbb irányba.

\section{Felhasznált irodalom}

Buda Mariann és Péter-Szarka Szilvia (2015): A kreatív klíma. Új irány az iskolai klíma és a konfliktuskezelés kutatásában In: Iskolakultúra, 3. sz., 3-17. URL: http://www.iskola kultura.hu/ikultura-folyoirat/documents/2015/09/01.pdf Utolsó letöltés: 2017. 05. 30. https://doi.org/10.17543/ISKKULT.2015.9.3

Kotschy Beáta (2003): Szakmai fejlesztő/fejlődő iskolák - a pedagógusképzés megújitásának egy lehetösége, Pedagógusképzés 1. évf. 1-2. sz 109-117.

Péter-Szarka Szilvia, Tímár Katalin és Balázs Tünde (2015): Az iskolai kreatív klíma kérdőív In: Alkalmazott Pszichológia, 2. sz., 107-132. URL: http://ap.elte.hu/wpcontent/uploads/2015/07/AP_2015_2_PETER_SZARKA_etal.pdf Utolsó letöltés: 2017. 05. 30.

Péter-Szarka Szilvia (é. n.): Kreatív klíma - A kreativitást támogató légkör megteremtésének iskolai lehetőségei (Géniusz Műhely 3.), URL: http://tehetseg.hu/sites/ default/files/geniusz_muhely/3peterszarka_6onl.pdf Utolsó letöltés: 2017. 05. 30.

Tímár Éva (1999): A nevelőtestületi klíma mérése a PKP jelű eszközzel, Békéscsaba, Békés Megye Képviselő-testülete Pedagógiai Intézete és Tanulási Képességet Vizsgáló Szakértői és Rehabilitációs Bizottsága.

Tímár Éva (2006): Tantestületi légkörvizsgálat In: Iskolakultúra, 3. sz., 11-23. URL: http://epa.oszk.hu/00000/00011/00102/pdf/iskolakultura_EPA00011_2006_03_ 011-023.pdf Utolsó letöltés: 2017. 05. 30.

Széll Krisztián (2016): Iskolai légkör és eredményesség. Előadás a HUCER konferencián, 2016. május 26-án, Kaposváron. 